This document was prepared in conjunction with work accomplished under Contract No. DE-AC09-96SR18500 with the U.S. Department of Energy.

This work was prepared under an agreement with and funded by the U.S. Government. Neither the U. S. Government or its employees, nor any of its contractors, subcontractors or their employees, makes any express or implied: 1 . warranty or assumes any legal liability for the accuracy, completeness, or for the use or results of such use of any information, product, or process disclosed; or 2 . representation that such use or results of such use would not infringe privately owned rights; or 3 . endorsement or recommendation of any specifically identified commercial product, process, or service. Any views and opinions of authors expressed in this work do not necessarily state or reflect those of the United States Government, or its contractors, or subcontractors. 
To be published in the Proceedings of PVP2007 2007 ASME Pressure Vessels and Piping Division Conference

July 22-26, 2007, San Antonio, Texas

PVP2007-26730

\title{
LITERATURE SURVEY OF GASEOUS HYDROGEN EFFECTS ON THE MECHANICAL PROPERTIES OF CARBON AND LOW ALLOY STEELS
}

\author{
P. S. Lam \\ R. L. Sindelar \\ T. M. Adams \\ Materials Science and Technology \\ Savannah River National Laboratory \\ Aiken, SC 29808
}

\begin{abstract}
Literature survey has been performed for a compendium of mechanical properties of carbon and low alloy steels following hydrogen exposure. The property sets include yield strength, ultimate tensile strength, uniform elongation, reduction of area, threshold stress intensity factor, fracture toughness, and fatigue crack growth. These properties are drawn from literature sources under a variety of test methods and conditions. However, the collection of literature data is by no means complete, but the diversity of data and dependency of results in test method is sufficient to warrant a design and implementation of a thorough test program. The program would be needed to enable a defensible demonstration of structural integrity of a pressurized hydrogen system. It is essential that the environmental variables be well-defined (e.g., the applicable hydrogen gas pressure range and the test strain rate) and the specimen preparation be realistically consistent (such as the techniques to charge hydrogen and to maintain the hydrogen concentration in the specimens).
\end{abstract}

\section{INTRODUCTION}

An infrastructure of new and existing pipelines and systems will be required to carry and to deliver hydrogen as an alternative energy source under the hydrogen economy. Carbon and low alloy steels of moderate strength are currently used in hydrogen delivery systems as well as in the existing natural gas systems. It is critical to understand the material response of these standard pipeline materials specified by the American Petroleum Institute (API) [1] when they are subject to pressurized gases of pure hydrogen or its mixture with methane since hydrogen is well known in deteriorating the mechanical properties of steels.

A literature survey for existing mechanical property data on carbon and low alloy steels exposed to hydrogen gas was conducted to support this program for hydrogen pipeline life management. This paper documents the data available in the open literature.

In the evaluation of the fitness-for-service for the line pipes used to transport hydrogen gas, the mechanical properties relevant to new construction or extended life of existing systems include the yield stress or yield strength $\left(\sigma_{y}\right)$; ultimate tensile strength (UTS); elongation; reduction of area; fracture toughness expressed by the critical stress intensity factor $\mathrm{K}_{\mathrm{IC}}$ or $\mathrm{K}_{\mathrm{JC}}$, J-integral (J), or crack growth resistance curve (J-R); the stress intensity factor threshold or the stress intensity factor at crack arrest $\left(\mathrm{K}_{\mathrm{th}}\right)$ below which no crack growth in the hydrogen environment is likely; and the fatigue crack growth rate (da/dN, where $\mathrm{a}$ is the crack length and $\mathrm{N}$ is the number of cycles). The fatigue testing is typically in terms of the difference of the maximum and minimum stress intensity factors or $\Delta \mathrm{K}=\mathrm{K}_{\max }-$ $\mathrm{K}_{\min }$, and the cyclic stress ratio, $\mathrm{R}=\mathrm{K}_{\min } / \mathrm{K}_{\max }$.

The change of mechanical properties is caused by the material response to hydrogen. However, the form of exposure or the type of attack directly affects the degradation mechanism in the materials, and results in various, sometimes 
opposite, effects [2] such as reported on the strain hardening or softening behavior. This paper will only document the mechanical property changes due to hydrogen-environmental embrittlement. The embrittlement due to direct chemical interaction between the gaseous hydrogen and the metals, as well as the internal embrittlement related to steel-making process, are out of the scope of the paper.

As pointed out by many authors, for example, Jewett et al (1973) [3],the mechanical properties of materials in a hydrogen environment cannot be compared on an equal basis because material composition, strain rate, testing procedure including the hold time prior to testing, sample preparation including charging method, hydrogen pressure and purity, etc. will affect the test results. In general, the change in the elastic properties is insignificant with the presence of hydrogen. However, the deformation capacity (ductility), fracture mechanics properties including fracture toughness and fatigue crack propagation characteristics are deteriorated as the hydrogen pressure increases. Typical test results in the open literature for carbon steels relevant to the pipeline materials are collected and are documented in this paper.

In this paper, the hydrogen affected tensile properties are first documented, followed by threshold stress intensity factor, the fracture toughness, and the fatigue crack growth data. Information on test pressure, temperature, strain rate, and gas purity are reported as appropriate, and the original work is referenced and is traceable if more detailed information of the experiments is needed. The collection of literature data is by no means complete, but the diversity of data is sufficient to warrant a conclusion that a thorough test program must be implemented. It is essential that the environmental variables be well-defined (particularly, the hydrogen gas pressure range and the strain rate) and the specimen preparation be realistically consistent (such as the hydrogen charge technique and to maintain the hydrogen concentration in the steels). In addition, to facilitate the predictive methodology and the fitness-for-service assessment analyses, the companion tensile testing for the full stress-strain curve should be performed along with the fracture mechanics property testing including fatigue crack growth.

\section{TENSILE PROPERTIES}

The tensile properties found in the literature typically include one or more of the following: yield stress, ultimate tensile strength, elongation, and reduction of area. They were reported mainly to demonstrate the hydrogen effects at various levels of pressure or concentration. The data may be useful for codified analyses which require strength information of the steels. However, for a realistic structural analysis or fracture performance analysis with the finite element method, in general, a full stress-strain curve beyond linear elasticity up to failure would be required.

A comprehensive mechanical property report on the hydrogen embrittlement effects on various structural alloys including (but not limited to) carbon steels can be found in Reference 3, which is a summary of a research project sponsored by National Aeronautics and Space Administration (NASA) prior to 1973. In the experimental programs for the tensile properties, the researchers used un-notched and notched specimens. The notched specimens provided stress concentration in the gage section so the hydrogen concentration is enhanced locally resulting in a more pronounced effect. However, the test data based on this type of specimens may be inadequate for stress analysis in structural integrity-related issues; rather, they do provide a convenient screening method in selecting the materials of construction. Therefore, in the current paper, only the tensile properties derived from unnotched specimens are reported unless otherwise identified.

The earliest tensile test conducted in hydrogen gas up to 2205 psig (15.2 MPa or $150 \mathrm{~atm}$ ) for $0.22 \%$ carbon steel was carried out by Hofmann and Rauls in 1961 [4] as quoted in Reference 3. Their results on tensile ductility are summarized in Table 1 and plotted in Figure 1 . Table 1 also provides additional information for this material when the tests were performed in air and in 1470 psig argon gas (inert environments). The tensile strength of this material in hydrogen was not reported by the original researchers.

Table 1 Tensile ductility data for $0.22 \%$ carbon steel (normalized at $900^{\circ} \mathrm{C}$ ) in hydrogen gas with various pressures [3]

\begin{tabular}{|c|c|c|c|c|}
\hline $\begin{array}{c}\text { Pressure } \\
\text { psig }\end{array}$ & $\begin{array}{c}\text { Pressure } \\
\text { atm }\end{array}$ & $\begin{array}{c}\text { UTS } \\
\text { ksi }\end{array}$ & $\begin{array}{c}\text { Elongation } \\
\text { gage: } 30 \mathrm{~mm} \text { ) } \\
\%\end{array}$ & $\begin{array}{c}\text { Reduction } \\
\text { of Area } \\
\%\end{array}$ \\
\hline $\begin{array}{c}\text { ambient } \\
\text { (Air) }\end{array}$ & 1 (Air) & 70.8 & 32 & 64 \\
\hline $147\left(\mathrm{H}_{2}\right)$ & $10\left(\mathrm{H}_{2}\right)$ & & 34.5 & 52 \\
\hline $294\left(\mathrm{H}_{2}\right)$ & $20\left(\mathrm{H}_{2}\right)$ & & 33 & 47 \\
\hline $735\left(\mathrm{H}_{2}\right)$ & $50\left(\mathrm{H}_{2}\right)$ & & 30 & 50 \\
\hline $1470\left(\mathrm{H}_{2}\right)$ & $100\left(\mathrm{H}_{2}\right)$ & & 30 & 36.5 \\
\hline $2205\left(\mathrm{H}_{2}\right)$ & $150\left(\mathrm{H}_{2}\right)$ & & 26 & 28 \\
\hline $\begin{array}{c}1470 \\
(\text { Argon })\end{array}$ & $\begin{array}{c}100 \\
(\text { Argon })\end{array}$ & 36 & 62 \\
\hline
\end{tabular}

The cold-drawn $0.22 \%$ carbon steel was used in another test, again by Hofmann and Rauls [5]. The lowering of the UTS is shown in Figure 2 (reproduced from Reference 3). The ductility data obtained for Armco iron and $0.45 \%$ carbon steel under gaseous hydrogen from 14.7 to 2205 psig were also reported [6] and are replotted in Figure 3. Both the UTS and the ductility of these carbon steels decrease as the hydrogen pressure increase from 14.7 to 2205 psig. Furthermore, these authors [6] correlated their ductility data in terms of carbon content of the test specimens (Figure 4). 


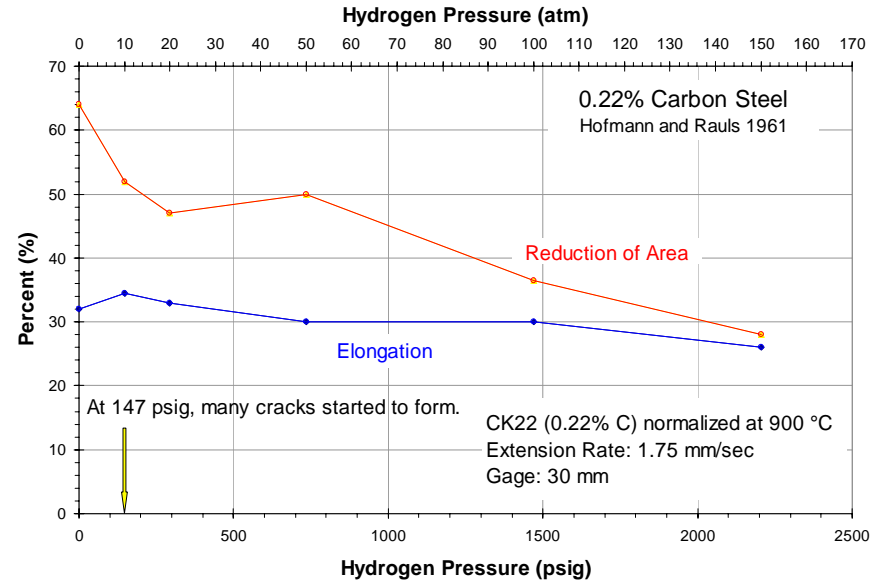

Figure 1 Elongation and reduction of area for $0.22 \%$ carbon steel in gaseous hydrogen up to 2205 psig (15.2 $\mathrm{MPa}$ or $150 \mathrm{~atm})$.

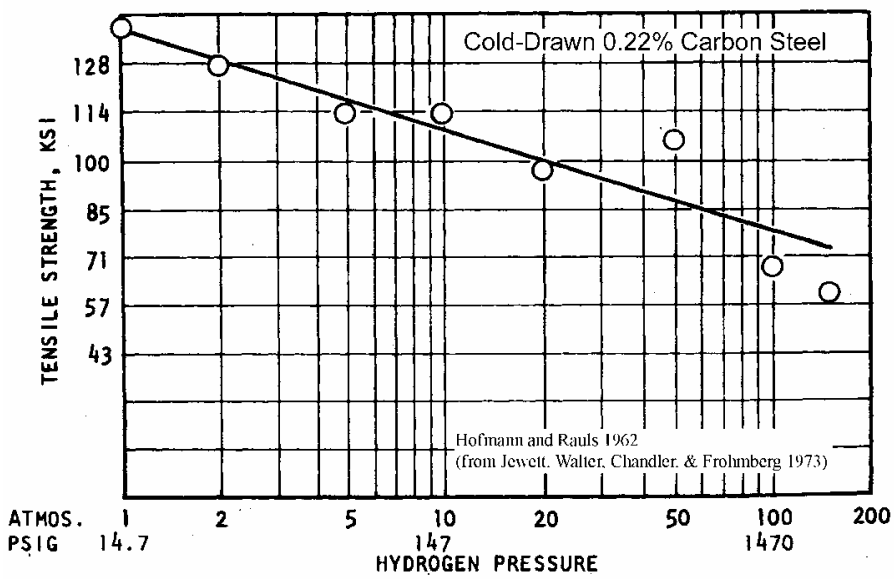

Figure 2 The tensile strength of cold-drawn $0.22 \%$ carbon steel decreases when the ambient hydrogen pressure increases [5].

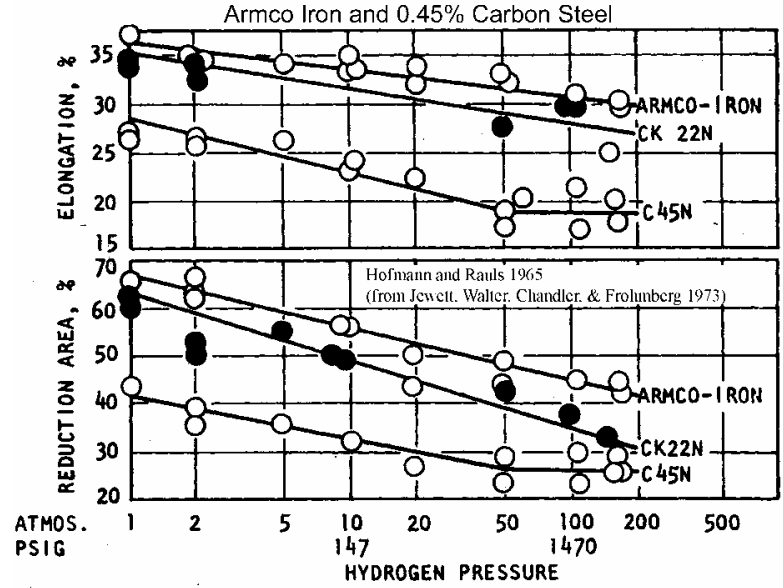

Figure 3 The ductility of Armco iron and $0.45 \%$ carbon steel decreases when the ambient hydrogen pressure increases [6].

For the materials in Figure 3, the numerical comparison of UTS in air and in hydrogen is shown in Table 2, in which only the un-notched data were extracted from Table 5 in Reference 3. It is noted that the UTS did not change due to the high pressure hydrogen. However, when the notched specimens were used, a 30\% reduction in UTS was observed in 2205 psig hydrogen gas $[3,6]$. It is believed that the hydrogen concentration was further enhanced near the root of the notch due to stress concentration.

Table 2 Un-notched tensile strength in air and in hydrogen [6]

\begin{tabular}{|l|c|c|}
\hline \multirow{2}{*}{ Material } & \multicolumn{2}{|c|}{ UTS (ksi) } \\
\cline { 2 - 3 } & Air & $\begin{array}{c}\text { Hydrogen at 2205 } \\
\text { psig }\end{array}$ \\
\hline Armco Iron & 51.4 & 48.6 \\
\hline $0.22 \%$ C Normalized & 71 & 71 \\
\hline $0.45 \%$ C Normalized & 96.2 & 96.2 \\
\hline
\end{tabular}

Figure 4 was reproduced from Reference 3 and shows the dependence of material ductility on the carbon content. It is clear that both elongation and reduction of area are reduced significantly from the values in the air. In this particular case, the hydrogen gas is 2205 psig (15.2 MPa or $150 \mathrm{~atm})$. 


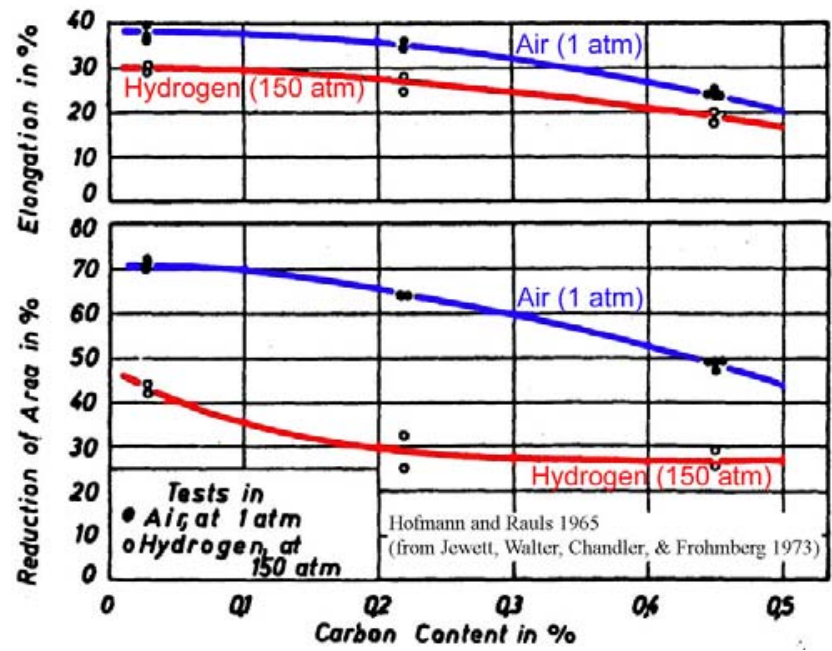

Figure 4 Effect of ductility change as a function of carbon content for specimens in air (1 atm) and in high pressure hydrogen gas (150 atm), respectively [3].

Table 8 of Reference 3 also lists the tensile test results for 36 iron, nickel, titanium, aluminum, and copper-base alloys in helium (inert environment) and in hydrogen. The pressure range for both gases was from 7000 to 10,000 psig. The yield stress, tensile strength, elongation, and reduction of area were originally reported by Walter and Chandler (1969) [7]. The carbon steels of moderate strength from that investigation include ASTM A-515 Gr. 70, AISI 1042 Normalized, AISI 1020, and Armco Iron. All these materials were subject to 10,000 psig of helium or hydrogen. The elongation and reduction of area from that work are presented graphically in Figure 5 to demonstrate the effect of high pressure hydrogen. However, the yield stress and the UTS were essentially unchanged (the maximum variation is about $2 \mathrm{ksi}$ ). These values are listed in Table 3. This finding seems consistent with that reported by Hofmann and Rauls [6] (see Table 2)

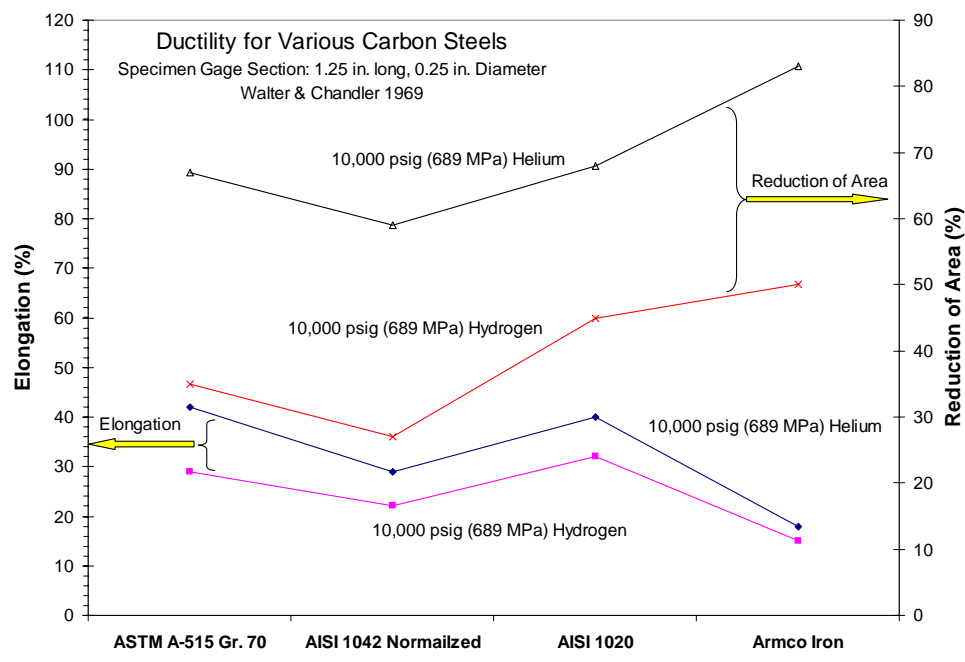

Figure 5 Comparison of the ductility for carbon steels in 1000 psig helium and in 1000 psig hydrogen.

Table 3 Tensile properties for some carbon steels under 10,000 psig of helium and hydrogen [3]

\begin{tabular}{|l|c|c|c|c|c|c|c|c|}
\hline \multirow{2}{*}{ Material } & \multicolumn{2}{|c|}{$\begin{array}{c}\text { Yield Stress } \\
\text { ksi }\end{array}$} & \multicolumn{2}{c|}{$\begin{array}{c}\text { Tensile Strength } \\
\text { ksi }\end{array}$} & \multicolumn{2}{c|}{$\begin{array}{c}\text { Elongation } \\
\%\end{array}$} & \multicolumn{2}{c|}{$\begin{array}{c}\text { Reduction of Area } \\
\%\end{array}$} \\
\cline { 2 - 9 } & $\mathrm{He}$ & $\mathrm{H}_{2}$ & $\mathrm{He}$ & $\mathrm{H}_{2}$ & $\mathrm{He}$ & $\mathrm{H}_{2}$ & $\mathrm{He}$ & $\mathrm{H}_{2}$ \\
\hline $\begin{array}{l}\text { ASTM } \\
\text { A-515 Gr. 70 }\end{array}$ & 45 & 43 & 65 & 64 & 42 & 29 & 67 & 35 \\
\hline $\begin{array}{l}\text { AISI 1042 } \\
\text { Normalized }\end{array}$ & 58 & $\mathrm{NA}^{*}$ & 90 & 89 & 29 & 22 & 59 & 27 \\
\hline AISI 1020 & 41 & 40 & 63 & 62 & 40 & 32 & 68 & 45 \\
\hline Armco Iron & 54 & NA $^{*}$ & 56 & 57 & 18 & 15 & 83 & 50 \\
\hline
\end{tabular}

${ }^{*}$ NA: not available. 
Reference 3 also reported that under high pressure hydrogen tensile testing, cracking was initiated on the outside surface of some specimens. Figure 6 shows the metallography of AISI 1020 specimen in 10,000 psig hydrogen gas tested by Walter and Chandler [7]. Multiple semi-circular cracks were seen to grow inward from the gage area and the crack orientation was perpendicular to the loading direction. Note that the typical composition for AISI 1020 is $0.17-0.24 \%$ C, $0.25-0.60 \% \mathrm{Mn}$, with the following representative tensile properties in air: minimum yield stress $36 \mathrm{ksi}$, UTS $58 \mathrm{ksi}$, elongation 36\%, and reduction of area $59 \%$.

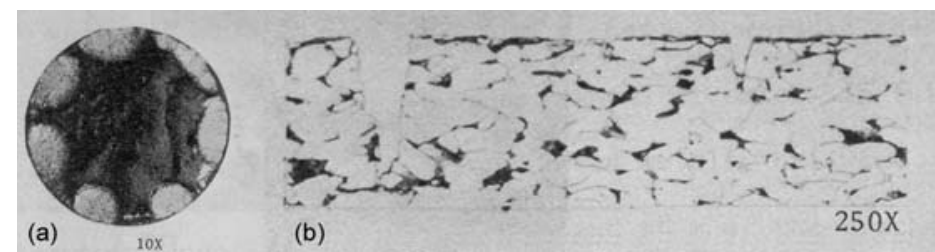

Figure 6 Metallography of un-notched tensile specimen indicated the formation of cracks in 10,000 psig hydrogen environment [7,3]: (a) Cross-section; (b) crack configurations.

Ellis, Bartlett and Knott (1990) [8] used an Amsler 500 ton press to apply various prestrains to steel blanks to modify (increase) the yield stress of the same alloys (P1 and P2, which contained 0.092 and $0.094 \mathrm{wt} . \%$ of carbon, respectively). The specimens were then cathodically charged with hydrogen with a thin layer of copper plate deposited onto the surface of the exposed specimen to prevent hydrogen from escaping. Subsequently, the specimens were held for 24 hours at room temperature so the hydrogen could be distributed uniformly in the specimen. Figure 7 shows that the $0.2 \%$ yield stress was reduced by the presence of hydrogen at various prestrain levels (or equivalently, at various yield stress level) of the alloys. Note that the UTS curves were available in the original work [8], but are deleted from Figure 7 because the data points were ambiguously presented in their published work.

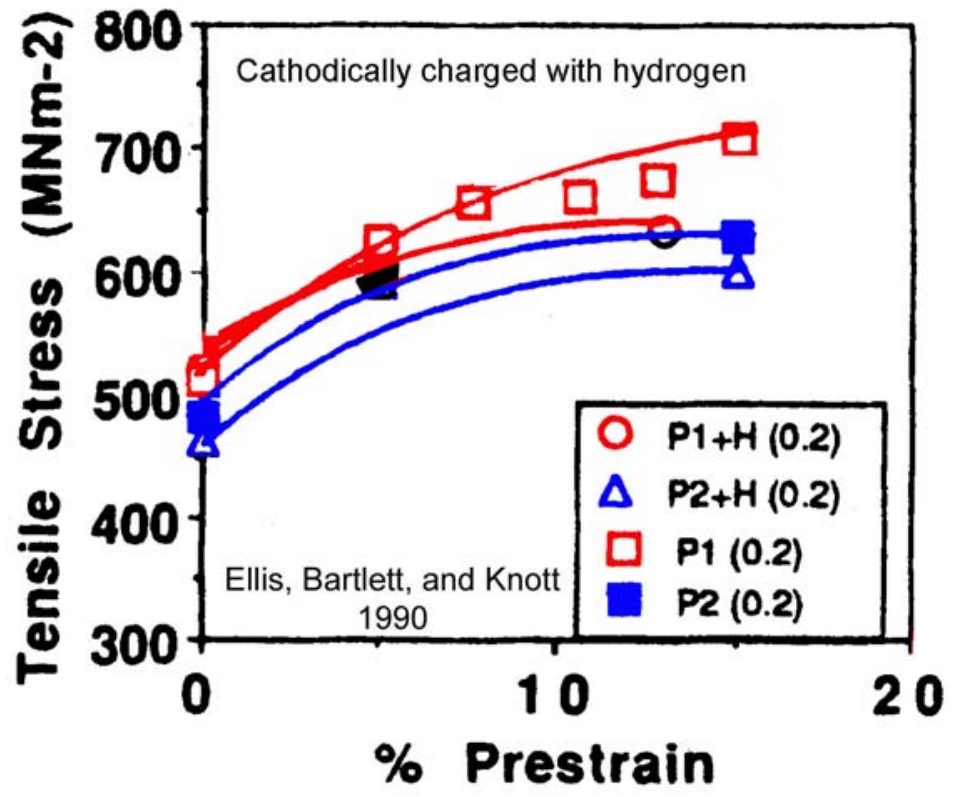

Figure 7 Hydrogen lowered the $0.2 \%$ yield stresses of the carbon steels (P1: quenched and tempered; P2: controlled rolled at $\left.-10^{\circ} \mathrm{C}\right)[8]$.

In contrast, results from the testing carried out by Pussegoda and Tyson (1981) [9] showed that the hydrogen would raise the flow properties of the materials (Figure 8). This is opposite to the findings of previously discussed results. Two representative sets of results are quoted here: 1) QT specimens (quenched and tempered); and 2) DQ specimens (directly quenched). The QT specimens were charged in hydrogen gas at $650{ }^{\circ} \mathrm{C}$ for 3 hours, quenched into an ice water bath, and stored in liquid nitrogen until testing. The hydrogen concentration was about $1 \mathrm{ppm}$ (wt.\%). The DQ specimens were cathodically charged in solution at a heated $\left(80{ }^{\circ} \mathrm{C}\right)$ solution to produce a range of hydrogen concentrations from 1 to $5 \mathrm{ppm}$, and then stored in nitrogen gas until testing. The tensile testing was conducted in a temperature range of -196 to $135{ }^{\circ} \mathrm{C}$. The charged tensile specimens tested above ambient temperature were electroplated with a thin layer of cadmium to prevent offgas. 

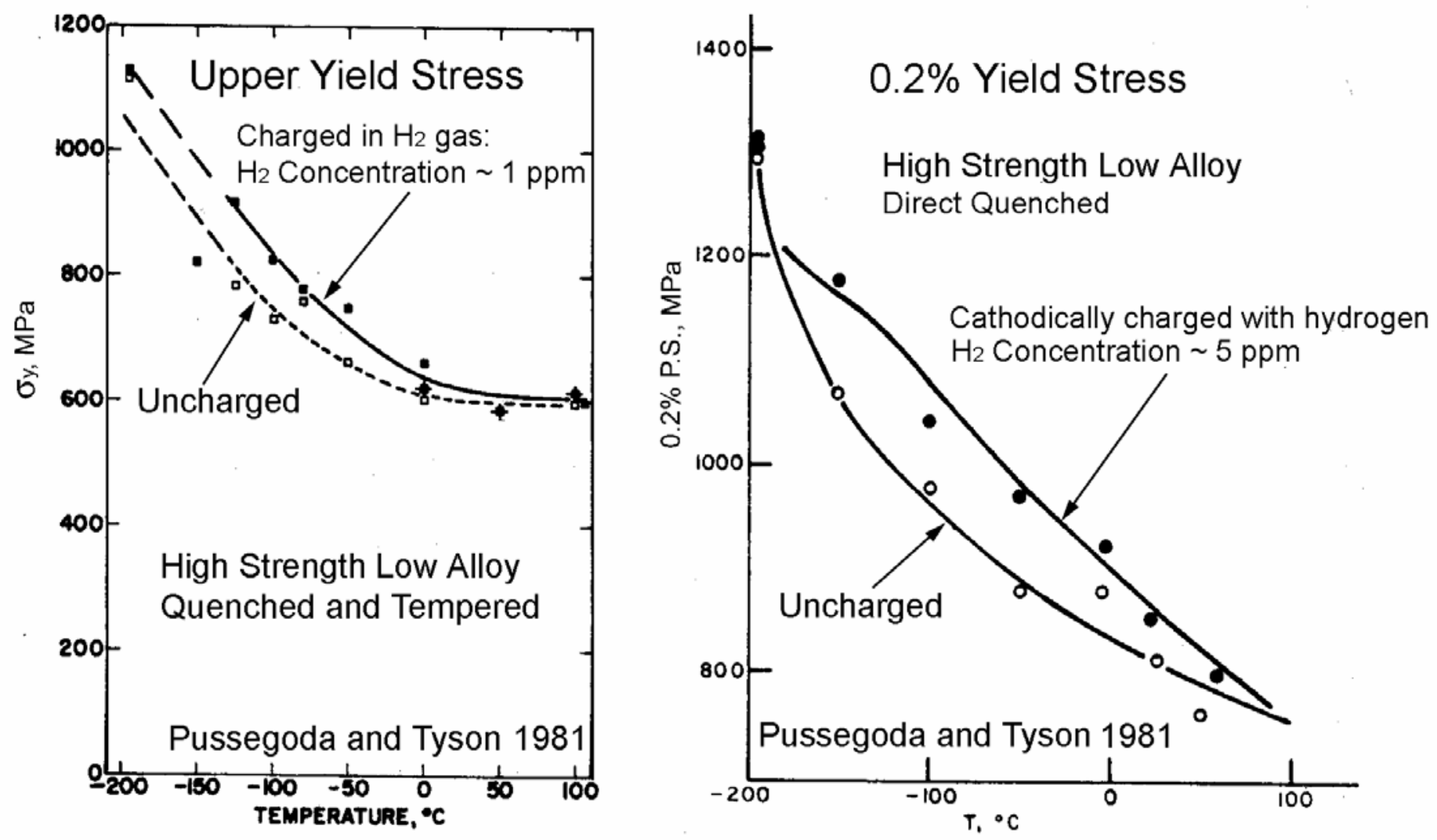

Figure 8 Hydrogen gas charged (left) and cathodically charged (right) tensile tests show that the yield stresses were increased due to hydrogen in the materials [9].

The temperature dependent ductility is expressed as embrittlement index (EI) and is shown in Figure 9 for various materials with different yield stresses. The embrittlement index is defined as

$$
\mathrm{EI}=\left(\varepsilon_{\mathrm{fu}}-\varepsilon_{\mathrm{fc}}\right) / \varepsilon_{\mathrm{fu}}
$$

and

$$
\varepsilon_{\mathrm{f}}=\ln \left(\mathrm{A}_{\mathrm{o}}-\mathrm{A}_{\mathrm{f}}\right)
$$

where $\varepsilon_{f}$ is the failure strain in the loading direction, $\mathrm{A}_{\mathrm{o}}$ is the original cross-sectional area of the tensile specimen, and $\mathrm{A}_{\mathrm{f}}$ is the cross-sectional area at failure. The additional subscripts "u" and "c" represent "uncharged" and "charged," respectively. 


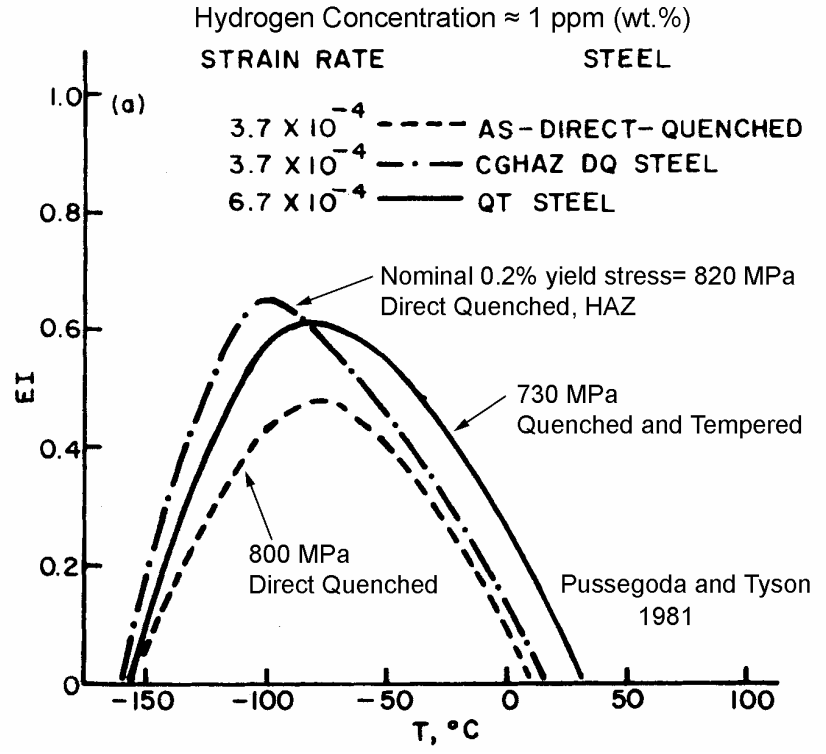

Figure 9 Temperature dependent embrittlement index for various materials [9].

Three types of Spanish line pipe steels were tested by Christenson et al. (1980) [10]. Their Pipe No. 2, which is similar to X42 steel specified by API [1], was also tested by Gutierrez-Solana and Elices (1982) [11] for fracture toughness. For Pipe No. 2, the smooth tensile specimens were cathodically charged, and immediately tested to minimize hydrogen loss. The unexposed and hydrogen-exposed tensile properties are summarized in Table 4, which shows that the effect of hydrogen on the tensile strength is not pronounced within the range of cathodic charge current densities (or the hydrogen concentration range, see the abscissa in Figure 10). Note that the hydrogen concentration in this work was up to about 40 ppm, which has far exceeded that of 1 to 5 ppm in Figure 8 and Figure 9 by Pussegoda and Tyson [9]. However, significant change in reduction of area was reported: about $80 \%$ in the longitudinal direction and about $60 \%$ in the transverse direction, as shown in Figure 10. The change in reduction of area is defined as $\left(\mathrm{RA}_{u}-\mathrm{RA}_{c}\right) / \mathrm{RA}_{u}$, where $\mathrm{RA}_{u}$ and $R A_{c}$ are the reduction of areas of the uncharged and charged specimen, respectively.

The changes in reduction of area for notched tensile specimens were also tested by Christenson et al. [10] and reported by Gutierrez-Solana and Elices [11]. Included in this test series, additional line pipe materials (Pipe No. 1 and a plate), along with Pipe No. 2 (discussed earlier in the last paragraph) were used [10]. These tensile specimens were double notched, and were tested in pressurized hydrogen atmosphere up to $34.5 \mathrm{MPa}(5000 \mathrm{psi})$. The resulting changes in reduction of area are plotted as a function of external hydrogen pressure and are shown in Figure 11 (the unexposed reduction of area for these notched specimens are not available). It can be seen from Figure 11 that the reduction of area has been severely deteriorated when the hydrogen pressure reaches $1000 \mathrm{psi}(6.9 \mathrm{MPa})$. It should be noted that these results were based on notched tensile specimens. Therefore, the data may be inadequate for stress analysis but can be used for comparison purposes. It is worth noting, however, Christenson et al. [10] did compare the fracture behavior and morphology from the two types of hydrogen charge (i.e., the cathodic charge in Figure 10 and the high pressure hydrogen atmosphere in Figure 11). They concluded that the qualitative correspondence between the hydrogen charge techniques could be established. For example, charging at $2.5 \mathrm{~mA} / \mathrm{cm}^{2}$ gave results similar to the testing in $3000 \mathrm{psi}(21 \mathrm{MPa})$ hydrogen environment. The general observation remains the same, that is, the strength of the materials was not affected significantly by hydrogen, but the ductility was decreased as a result of hydrogen exposure.

Table 4 Unexposed and hydrogen charged tensile properties of a Spanish pipeline material similar to X42

\begin{tabular}{|l|l|l|l|}
\hline $\begin{array}{l}\text { Pipe No. 2 } \\
\text { (similar to } \\
\text { X42) }\end{array}$ & $\begin{array}{l}0.2 \% \quad \text { Yield } \\
\text { Stress (MPa) }\end{array}$ & UTS (MPa) & $\begin{array}{l}\text { Reduction } \\
\text { of Area } \\
\text { (RA) }\end{array}$ \\
\hline Unexposed & $\begin{array}{l}266 \\
\text { (Longitudinal) }\end{array}$ & $\begin{array}{l}414 \\
\text { (Longitudinal) }\end{array}$ & $61 \%$ \\
\cline { 2 - 4 } & $\begin{array}{l}286 \\
\text { (Transverse) }\end{array}$ & $\begin{array}{l}417 \\
\text { (Transverse) }\end{array}$ & $51 \%$ \\
\hline $\begin{array}{l}\text { Cathodically } \\
\text { Charged } \mathrm{H}_{2}\end{array}$ & $\begin{array}{l}294 \\
\text { (Averaged) }\end{array}$ & 424(Averaged) & $\begin{array}{l}\text { change up } \\
\text { to 80\% }\end{array}$ \\
\hline
\end{tabular}

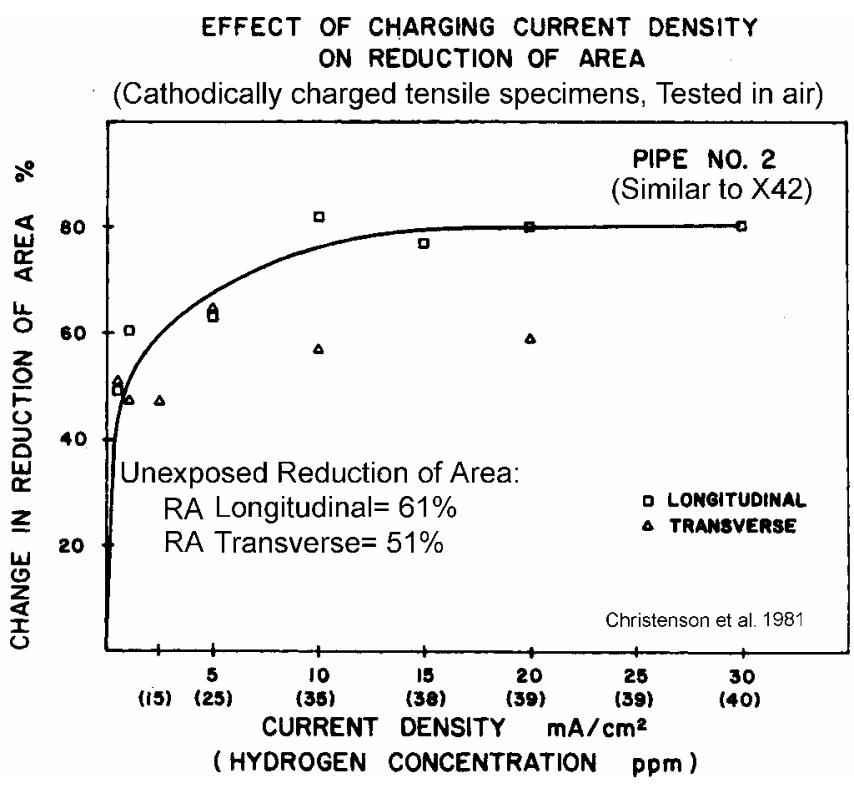

Figure 10 The change of reduction of area as a function of charge current density or hydrogen concentration for a line pipe material similar to $X 42[10]$. 
EFFECT OF $\mathrm{H}_{2}$ PRESSURE ON REDUCTION OF AREA (Notched tensile specimens in hydrogen gas environment)

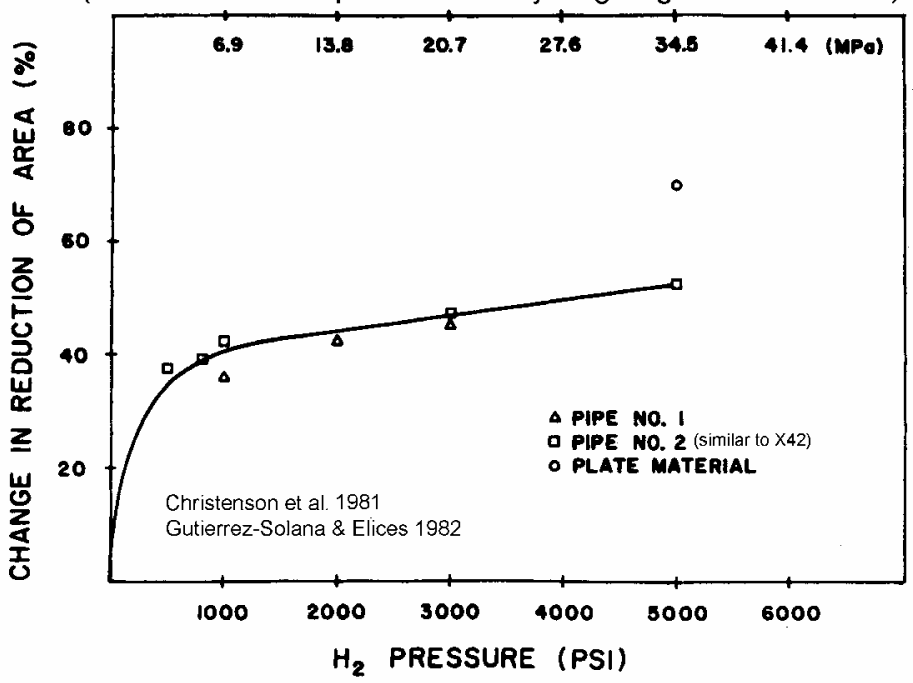

Figure 11 Change in reduction of area as a function of exposing hydrogen pressure for Spanish line pipe materials using double-notched tensile specimens $[10,11]$.

The tensile properties obtained in 1000 psig (6.9 MPa) hydrogen environment for some API pipeline materials (X42 and X70) and low carbon steels (A516 and A106B) were reported by Cialone and Holbrook (1988) in Table 2 of Reference 12, and by Holbrook, Cialone, Mayfield, and Scott (1982) in Table 2 of Reference 13, on their fatigue and subcritical crack growth studies. Because the tests were performed mainly within the same research group, their results are consolidated in Table 5. The carbon contents for these materials, X42, X70, A516, and A106B are, respectively, 0.26, $0.09,0.21$, and $0.26 \%$. For manganese contents, they are, respectively, $0.82,1.50,1.04$, and $0.57 \%$. The API X60 was also tested [13], but the properties in hydrogen were not reported. Therefore, the data for X60 are not included in this paper.

THRESHOLD STRESS INTENSITY FACTOR $\left(\mathrm{K}_{\mathrm{th}}\right.$ or $\left.\mathrm{K}_{\mathrm{H}}\right)$

Longinow and Phelps (1975) [14] used wedge-openingloaded (WOL) specimens to determine the critical stress intensity factor $\left(\mathrm{K}_{\mathrm{H}}\right)$ at which the crack arrest occurred in specimens exposed to hydrogen. The pre-cracked WOL specimens were loaded in air to 30 to $95 \%$ of the fracture toughness of the material in air, then exposed to 3000 to 14,000 psi (21 to $97 \mathrm{MPa}$ ) high purity hydrogen gas at ambient temperature. The stress intensity factor decreased as the crack propagation was initiated in hydrogen after an incubation time. As a result, $\mathrm{K}_{\mathrm{H}}$ is defined as the lowest stress intensity factor achieved in the testing, below which the crack propagation in hydrogen is unlikely. The critical crack size can be estimated with fracture mechanics principle and the value of $\mathrm{K}_{\mathrm{H}}$.

Longinow and Phelps investigated various carbon steels with a wide range of yield stress. When the values of $K_{H}$ were averaged based on the yield stress, they found that the behavior of $\mathrm{K}_{\mathrm{H}}$ seemed to form two separate groups: 1) steels with 85 to $113 \mathrm{ksi}$ (586 to $779 \mathrm{MPa}$ ) yield stress and with 126 to $153 \mathrm{ksi}$ (869 to $1055 \mathrm{MPa}$ ) yield stress. The results can be found in Reference 14 and are reproduced in Figure 12 of this paper.

Similarly, Cialone and Holbrook (1988) [12] performed subcritical crack growth experiments for X70 steel, X42 heat affected zone (HAZ), and a hardened X42 steel. The specimens were loaded in fixed displacement condition and tested in various pure gases and their mixtures with a total pressure of $6.9 \mathrm{MPa}(1000 \mathrm{psi})$ regardless the gas compositions. The initial displacement was selected from the fracture toughness test data where the crack initiation was observed. Only hardened X42 exhibited crack growth in the mixture of $60 \%$ hydrogen and $40 \%$ methane (by volume) with total pressure of 6.9 MPa. 
Table 5 Tensile properties for X42, X70, A516, and A106B in air and in 1000 psi (6.9 MPa) hydrogen gas [12,13]

\begin{tabular}{|c|c|c|c|c|c|}
\hline Steel & $\begin{array}{c}\text { Test } \\
\text { Environment }\end{array}$ & $\begin{array}{c}0.2 \% \text { Offset } \\
\text { Yield Stress } \\
\text { MPa (ksi) }\end{array}$ & $\begin{array}{c}\text { UTS } \\
\text { MPa (ksi) }\end{array}$ & $\begin{array}{c}\text { Elongation } \\
\text { in } 1 \text { inch gage } \\
\%\end{array}$ & $\begin{array}{c}\text { Reduction of } \\
\text { Area } \\
\%\end{array}$ \\
\hline \multirow{2}{*}{$\begin{array}{l}\text { X42 } \\
\text { Longitudinal }\end{array}$} & Air & $366(53)$ & $511(74)$ & 21 & 56 \\
\hline & $6.9 \mathrm{MPa} \mathrm{H}_{2}$ & 331 (48) & $483(70)$ & 20 & 44 \\
\hline \multirow{2}{*}{$\begin{array}{l}\text { X42 } \\
\text { Transverse }\end{array}$} & Air & $311(45)$ & $490(71)$ & 21 & 52 \\
\hline & $6.9 \mathrm{MPa} \mathrm{H}_{2}$ & 338 (49) & 476 (69) & 19 & 41 \\
\hline \multirow{2}{*}{$\begin{array}{l}\text { X70 } \\
\text { Longitudinal }\end{array}$} & Air & $584(85)$ & 669 (97) & 20 & 57 \\
\hline & $6.9 \mathrm{MPa} \mathrm{H}_{2}$ & 548 (79) & 659 (95) & 20 & 47 \\
\hline \multirow{2}{*}{$\begin{array}{l}\text { X70 } \\
\text { Transverse }\end{array}$} & Air & $613(89)$ & 702 (102) & 19 & 53 \\
\hline & $6.9 \mathrm{MPa} \mathrm{H}_{2}$ & $593(86)$ & $686(99)$ & 15 & 38 \\
\hline \multirow{2}{*}{ A516 } & Air & $372(54)$ & $538(78)$ & 17 & 70 \\
\hline & $6.9 \mathrm{MPa} \mathrm{H}_{2}$ & $365(53)$ & $552(80)$ & 20 & 43 \\
\hline \multirow{2}{*}{ A106B } & Air & $462(67)$ & $558(81)$ & 14 & 58 \\
\hline & $6.9 \mathrm{MPa} \mathrm{H}_{2}$ & $503(73)$ & $579(84)$ & 11 & 50 \\
\hline
\end{tabular}

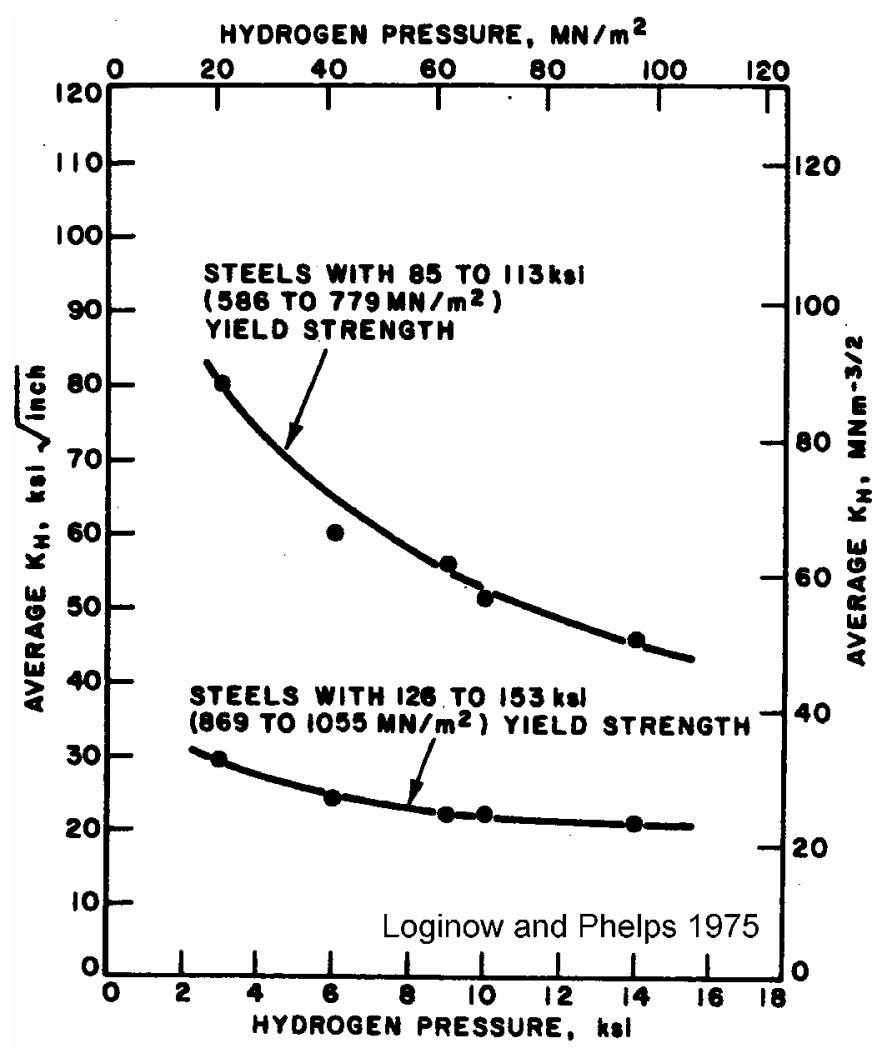

Figure 12 Threshold stress intensity factors at crack arrest in various hydrogen pressures [14].

\section{FRACTURE TOUGHNESS}

Fracture toughness properties are reported in the literature typically in terms of $\mathrm{K}_{\mathrm{IC}}$ (plane strain fracture toughness), $\mathrm{J}_{\mathrm{IC}}$ (elastic-plastic fracture toughness in terms of J-integral), crack growth resistance or J-R curve, and $\mathrm{dJ} / \mathrm{da}$ which is the slope of the fracture resistance curve and is related to the tearing capability of the material. The representative results in the open literature for hydrogen-exposed carbon steel fracture properties are summarized in this section.

Robinson and Stoltz (1981) [15] used double-edged notched specimens of A516 Grade 70 (0.21\% C, 1.04\% Mn) for J-R curve testing in air and in hydrogen at pressures from 3.45 to $34.5 \mathrm{MPa}$ (500 to $5000 \mathrm{psi}$ ). The test results are reproduced in Figure 13, from which they concluded that the hydrogen effect occurs at $3.45 \mathrm{MPa}$ (due to fracture mode change) and is saturated at $34.5 \mathrm{MPa}$. In addition, the slope of the $J$-R curve ( $\mathrm{dJ} / \mathrm{da}$, where $\mathrm{J}$ is the $\mathrm{J}$-integral and a is the crack length) remains nearly constant regardless of the hydrogen pressure, indicating that hydrogen does not affect the ductile tearing through the pearlite colonies, while the crack initiation $\mathrm{J}_{\mathrm{IC}}$ is related to the fracture of the ferrite that is controlled by the hydrogen-dislocation interaction. The numerical values of Figure 13 are tabulated in Table 6 . Note that $\mathrm{dJ} / \mathrm{da}$ is proportional to the Paris tearing modulus [16] which is related to the tearing capacity of the material. 
The fracture toughness for A106 Grade B carbon steel was determined alternatively with information from burst tests conducted by Robinson and Stoltz [15]. A longitudinal, 20\% part-through wall flaw was machined to each of the $10 \mathrm{~cm}$ diameter pipes. The test was performed with nitrogen gas and with 6.9 MPa hydrogen pressure plus overpressure nitrogen to burst. The estimated fracture toughness in the inert environment (nitrogen) is $\mathrm{K}_{\mathrm{IC}}=114 \mathrm{MPa} \sqrt{\mathrm{m}}(104 \mathrm{ksi} \sqrt{\mathrm{in}})$. Under 6.9 MPa hydrogen partial pressure, the burst test

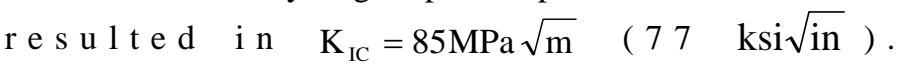

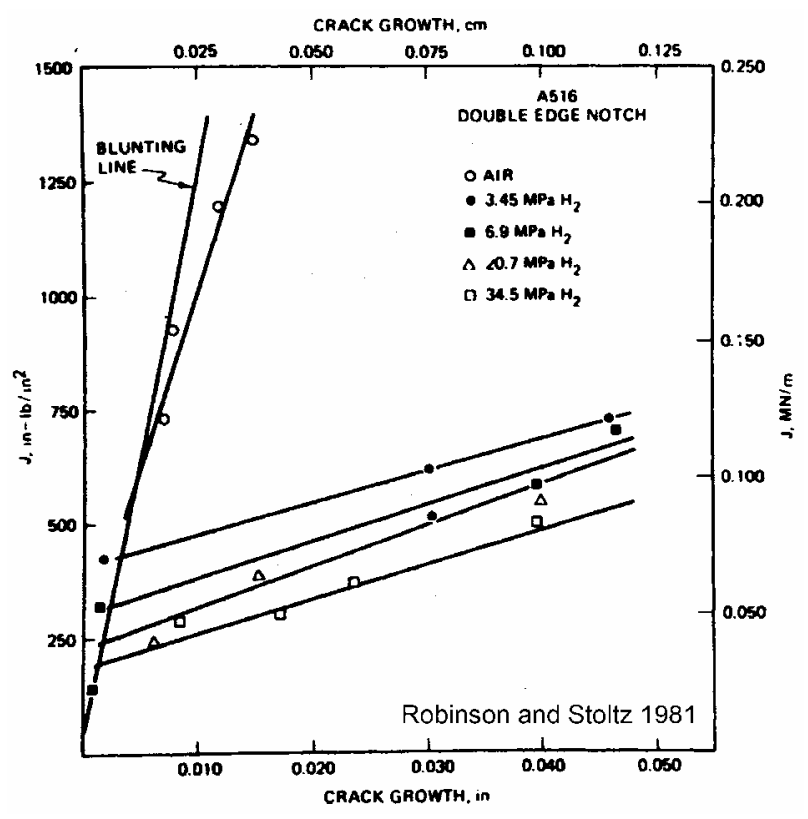

Figure 13 Crack growth resistance (J-R) curves for A516 Grade 70 in Air and in Hydrogen [15].

Table 6 Fracture toughness (J-R curve) for A516 Grade 70 in air and in hydrogen [15]

\begin{tabular}{|l|c|c|c|c|c|c|c|}
\hline \multirow{2}{*}{ A516-70 } & \multicolumn{3}{|c|}{$\mathrm{J}_{\mathrm{IC}}$} & \multicolumn{2}{|c|}{$\mathrm{K}_{\mathrm{IC}}$} & \multicolumn{2}{c|}{$\mathrm{dJ} / \mathrm{da}$} \\
\cline { 2 - 8 } & $\mathrm{MN} / \mathrm{m}$ & $\mathrm{kJ} / \mathrm{m}^{2}$ & in-lb/in $^{2}$ & $\mathrm{MPa} \sqrt{\mathrm{m}}$ & $\mathrm{ksi} \sqrt{\mathrm{in}}$ & $\mathrm{MPa}$ & $\mathrm{lb} / \mathrm{in}^{2}$ \\
\hline Air & 0.121 & 121 & 697 & 150 & 137 & 516 & $7.5 \times 10^{4}$ \\
\hline $\mathrm{H}_{2} 3.5 \mathrm{MPa}$ & 0.076 & 76 & 438 & 119 & 108 & 47 & $6.9 \times 10^{3}$ \\
\hline $\mathrm{H}_{2} 6.9 \mathrm{MPa}$ & 0.056 & 56 & 322 & 102 & 93 & 55 & $8.1 \times 10^{3}$ \\
\hline $\mathrm{H}_{2} 20.7 \mathrm{MPa}$ & 0.042 & 42 & 243 & 89 & 81 & 54 & $8.9 \times 10^{3}$ \\
\hline $\mathrm{H}_{2} 34.5 \mathrm{MPa}$ & 0.036 & 36 & 207 & 82 & 75 & 57 & $8.3 \times 10^{3}$ \\
\hline
\end{tabular}

Gutierrez-Solana and Elices [11] performed fracture toughness testing for a Spanish transmission pipeline material similar to X42 steel under hydrogen pressure. The three-point bend test was conducted in high pressure chamber with high purity hydrogen up to $6.5 \mathrm{MPa}$. Finite element analysis was used to verify the experimentally obtained J-integral values. In addition, burst tests were carried out for pipes with various configurations of longitudinal machined cracks. Similar to Robinson and Stoltz [15], the fracture toughness was estimated from the burst test data. The burst test specimens were first allowed sufficient time in the hydrogen environment to achieve maximum embrittlement, then pressurized to burst. The highest hydrogen pressure recorded was $16 \mathrm{MPa}$. The plane strain fracture toughness, $\mathrm{K}_{\mathrm{IC}}$, were calculated with analytical solution and plotted collectively with the three-point bend data in Figure 14. The numerical data are shown in Table 7 for the three-point bend test, and in Table 8 for the burst test. Note that the actual burst pressure was slightly higher than the hydrogen pressure for each test.

Fracture testing for J-R curves was reported by Cialone and Holbrook (1988) [12] for X42 and X70 under various gas condition with total pressure of 6.9 $\mathrm{MPa}$ independent of the composition of the gas mixtures. Figure 15 shows the comparison of the J-R curves for X42 in 6.7 MPa (1000 psig) pressure of nitrogen (inert condition) and in 6.7 MPa (1000 psig) hydrogen, respectively. The numerical values for crack initiation $\left(\mathrm{J}_{\mathrm{IC}}\right)$ and for the slope of the J-R curves $(\mathrm{dJ} / \mathrm{da})$ representing the tearing capability of the material [16] are listed in Table 9, from which the only significant reduction in $\mathrm{dJ} / \mathrm{da}$ can be seen in the case of X70. 


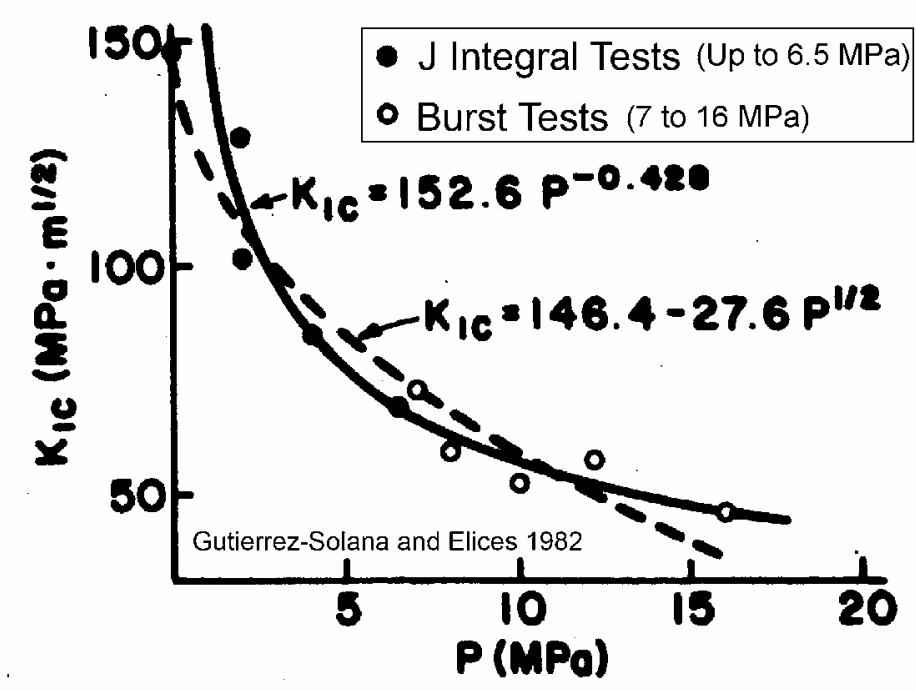

Figure 14 Hydrogen pressure-dependent fracture toughness for a Spanish line pipe material similar to API X42 [11].

Table 7 Three-point bend fracture toughness test results for a Spanish line pipe material similar to API X42 under hydrogen pressure (see Figure 14) [11]

\begin{tabular}{|c|c|c|c|c|}
\hline $\begin{array}{c}\mathrm{H}_{2} \text { Pressure } \\
(\mathrm{MPa})\end{array}$ & $\begin{array}{c}\mathrm{J}_{\mathrm{IC}} \\
\left(\mathrm{kJ} / \mathrm{m}^{2}\right)\end{array}$ & $\begin{array}{c}\mathrm{K}_{\mathrm{JC}} \\
(\mathrm{MPa} \sqrt{\mathrm{m}})\end{array}$ & $\begin{array}{c}\mathrm{dJ} / \mathrm{da} \\
(\mathrm{MPa})\end{array}$ & $\begin{array}{c}\delta_{\mathrm{c}}^{* *} \\
(\mathrm{~mm})\end{array}$ \\
\hline 0 & $99.8 \pm 3.8$ & 147 & 111 & 0.134 \\
\hline 2 & $76 / 48$ & $128 / 101$ & NA & NA \\
\hline 4 & $33.3 \pm 2.1$ & 85 & 36 & 0.035 \\
\hline 6.5 & $22.3 \pm 2.1$ & 69 & 31 & 0.029 \\
\hline
\end{tabular}

$* * \delta_{\mathrm{c}}$ is the critical crack tip opening displacement (CTOD), obtained from crack mouth opening displacement (CMOD) measured when $\mathrm{J}=\mathrm{J}_{\mathrm{IC}}$.

Table 8 Fracture toughness data determined by burst test for a Spanish line pipe material similar to API X42 under hydrogen pressure (see Figure 14) [11]

\begin{tabular}{|c|c|c|}
\hline $\mathrm{H}_{2}$ Pressure (MPa) & $\begin{array}{c}\text { Burst Pressure } \\
(\mathrm{MPa})\end{array}$ & $\mathrm{K}_{\mathrm{IC}}(\mathrm{MPa} \sqrt{\mathrm{m}})$ \\
\hline 7 & 9.4 & 73 \\
\hline 8 & 8.4 & 59 \\
\hline 10 & 11.1 & 53 \\
\hline 12.2 & 15.8 & 57 \\
\hline 16.0 & 16.8 & 46 \\
\hline
\end{tabular}

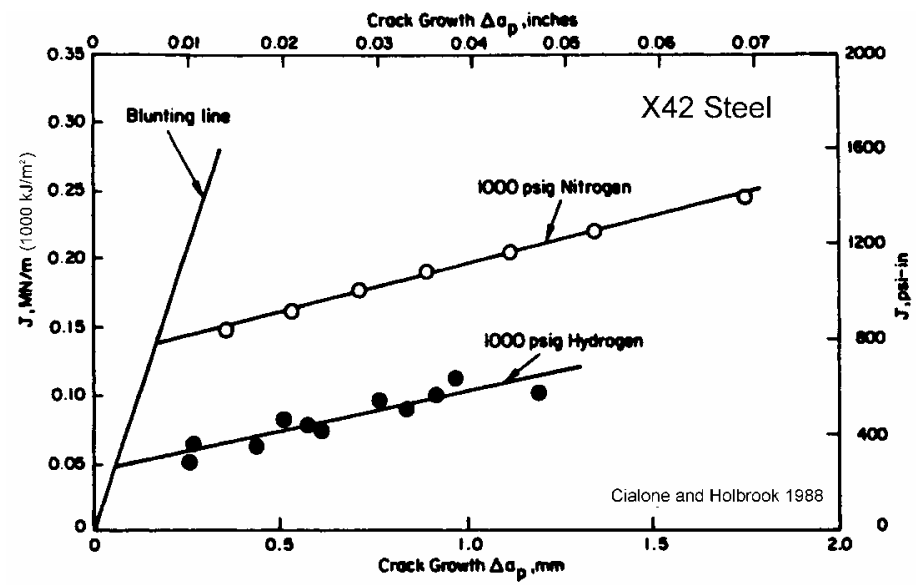

Figure 15 The crack growth resistance (J-R) curves for X42 base metal in $6.9 \mathrm{MPa}$ (1000 psig) pressure of nitrogen and in $6.9 \mathrm{MPa}$ of hydrogen [12].

Table 9 Fracture toughness ( $\mathrm{J}_{\mathrm{IC}}$ and $\mathrm{dJ} / \mathrm{da}$ ) for $\mathrm{X} 42$ and $\mathrm{X} 70$ in 6.9 MPa nitrogen and in 6.9 MPa hydrogen [12]

\begin{tabular}{|c|c|c|c|c|}
\hline \multirow{2}{*}{ Material } & \multicolumn{2}{|c|}{$\mathrm{J}_{\text {IC }}(\mathrm{MN} / \mathrm{m})$} & \multicolumn{2}{c|}{$\begin{array}{c}\mathrm{dJ} / \mathrm{da}(\mathrm{MPa} \text { or } \\
\left.\mathrm{MN} / \mathrm{m}^{2}\right)\end{array}$} \\
\cline { 2 - 5 } & $\begin{array}{c}\mathrm{N}_{2} 6.9 \\
\mathrm{MPa}\end{array}$ & $\begin{array}{c}\mathrm{H}_{2} 6.9 \\
\mathrm{MPa}\end{array}$ & $\begin{array}{c}\mathrm{N}_{2} 6.9 \\
\mathrm{MPa}\end{array}$ & $\begin{array}{c}\mathrm{H}_{2} 6.9 \\
\mathrm{MPa}\end{array}$ \\
\hline X42 & 0.14 & 0.05 & 70 & 63 \\
\hline X70 & 0.17 & 0.04 & 251 & 23 \\
\hline X42 HAZ & 0.02 & 0.01 & 97 & 69 \\
\hline
\end{tabular}

Recently, Charpy V-notch impact tests, elastic-plastic fracture toughness tests, and constant load fatigue tests were carried out by Zawierucha and Xu (2005) [17] using API 5L Grade B steel. This steel received multiple certifications as API 5L Product Specification Level (PSL) 1 Grade B [1], ASTM A53 Grade B, ASME SA53 Grade B, ASTM A106 Grade B/C, and ASMESA-106 Grade B/C. The carbon and manganese contents are respectively 0.18 and $1.06 \%$, with carbon equivalent ${ }^{\dagger}$ (CE) 0.37. It was tested as-rolled and normalized ( $900{ }^{\circ} \mathrm{C}$ for one hour followed by air cool) conditions. The normalization increases the $0.2 \%$ Young's modulus, UTS, elongation, and reduction of area from 299

\footnotetext{
${ }^{\dagger}$ For carbon content greater than $0.12 \%$, API 5L [1] specifies that $\mathrm{CE}=\mathrm{C}+\mathrm{Mn} / 6+(\mathrm{Cr}+\mathrm{Mo}+\mathrm{V}) / 5+(\mathrm{Ni}+\mathrm{Cu}) / 15$
} 
$\mathrm{MPa}, 518 \mathrm{MPa}, 28 \%$, and $54.9 \%$, respectively, to $371 \mathrm{MPa}$, $539 \mathrm{MPa}, 32.9 \%$, and $61 \%$.

Typically, the effects of hydrogen on the J-R curve for API $5 \mathrm{~L}$ Grade B can be seen in Figure 16, where the compact tension specimens were tested in 13.8 MPa (2000 psi) nitrogen and in $13.8 \mathrm{MPa}$ (2000 psi) hydrogen, respectively. The complete results of fracture toughness testing can be found in Table 10. The $\mathrm{J}_{\mathrm{IC}}$ data in Table 10 are plotted in Figure 17. Note that the specimen tested in $13.8 \mathrm{MPa}$ nitrogen did not meet the $\mathrm{J}_{\mathrm{IC}}$ requirement specified by ASTM E 1820 [18]. Therefore, the fracture toughness was obtained by correlating the Charpy impact test results [19]. The estimated $\mathrm{K}_{\mathrm{IC}}$ for the as-rolled materials is $120 \mathrm{MPa} \sqrt{\mathrm{m}}$ (in nitrogen with 13.8 MPa), and the equivalent $\mathrm{J}_{\mathrm{IC}}$ is $70 \mathrm{~kJ} / \mathrm{m}^{2}$.

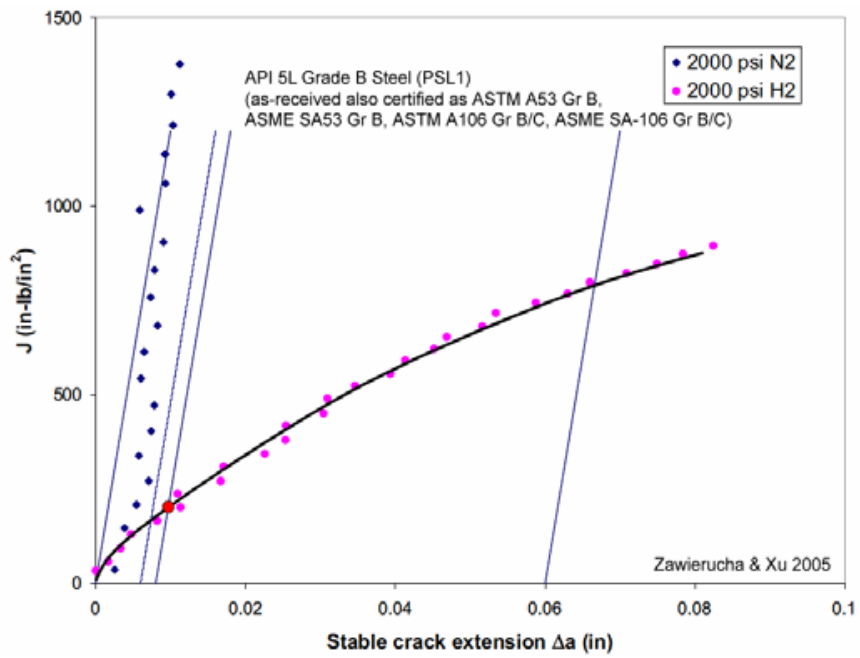

Figure 16 The J-R curves for API $5 \mathrm{~L}$ Grade B in $13.8 \mathrm{MPa}$ (2000 psi) nitrogen and in $13.8 \mathrm{MPa}(2000 \mathrm{psi})$ hydrogen [17].

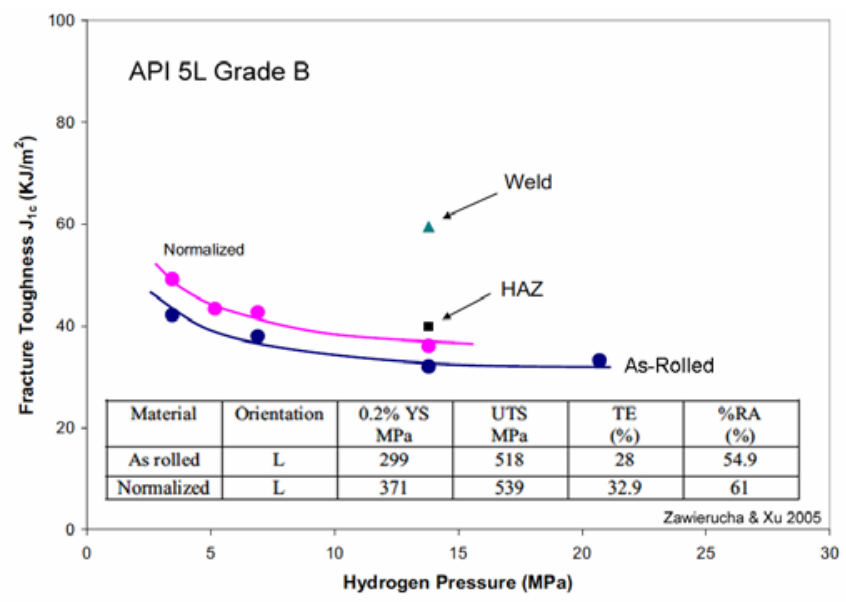

Figure 17 The pressure dependent $\mathrm{J}_{\mathrm{IC}}$ for API $5 \mathrm{~L}$ Grade B in hydrogen [17]

\section{FATIGUE CRACK GROWTH}

The fatigue crack growth rate (i.e., da/dN) of materials is a function of the maximum stress $\left(\mathrm{K}_{\max }\right)$, minimum stress $\left(\mathrm{K}_{\min }\right)$, stress range $\left(\Delta \mathrm{K}=\mathrm{K}_{\max }-\mathrm{K}_{\min }\right)$, stress ratio $\left(\mathrm{R}=\mathrm{K}_{\min } / \mathrm{K}_{\max }\right)$, and cyclic frequency. Because vast amounts of data exist in the open literature for carbon steels, only typical results of fatigue testing in pressurized hydrogen gas environment for API 5L line pipe materials with moderate strength [12,17], and for ASME SA-105 Grade II steel [20], are reported in this section of the paper.

The API X42 and X70 line pipe steels were used by Cialone and Holbrook (1988) [12] in a comprehensive hydrogen test program including the tensile, subcritical crack growth, and fracture tests which have been documented in previous sections. Some of their fatigue test data of fatigue crack growth rate tests are shown in Figure 18, from which the fatigue crack growth rates in $6.9 \mathrm{MPa}(1000 \mathrm{psig})$ hydrogen and in 6.9 $\mathrm{MPa}$ (1000 psig) nitrogen can be compared. In these two cases, low stress ratio $(\mathrm{R}=0.1)$ were used in testing. It can be seen that da/dN appears to be higher in X42 steel than in X70 at the same $\Delta \mathrm{K}$ level. In the case of X42, the fatigue crack growth rate can be 150 times greater than that in the nitrogen, under the same 6.9 MPa pressure. The tests were also carried out at higher stress ratios ( $\mathrm{R}$ ranges from 0.1 to 0.8). These results for X42 are summarized in Figure 19. 
Table 10 Fracture toughness for API 5L Grade B exposed to various pressures of hydrogen [17]

\begin{tabular}{|c|c|c|c|c|c|c|c|}
\hline \multirow{2}{*}{ Material } & \multicolumn{2}{|c|}{$\mathrm{H}_{2}$ Pressure } & Loading Rate & \multicolumn{2}{|c|}{$\mathrm{J}_{\mathrm{IC}}$} & \multicolumn{2}{c|}{$\mathrm{K}_{\mathrm{JC}}$} \\
\cline { 2 - 7 } & $\mathrm{MPa}$ & $\mathrm{psi}$ & $\mathrm{mm} / \mathrm{min}$ & $\mathrm{kJ} / \mathrm{m}^{2}$ & $\mathrm{in}-\mathrm{lb} / \mathrm{in}^{2}$ & $\mathrm{MPa} \sqrt{\mathrm{m}}$ & $\mathrm{ksi} \sqrt{\mathrm{in}}$ \\
\hline As-rolled & 13.8 & 2000 & 0.5 & 33.8 & 193 & 84 & 76 \\
\hline As-rolled & 3.5 & 500 & 0.05 & 42.2 & 241 & 94 & 86 \\
\hline As-rolled & 6.9 & 1000 & 0.05 & 38.0 & 217 & 89 & 81 \\
\hline As-rolled & 13.8 & 2000 & 0.05 & 32.0 & 183 & 81 & 74 \\
\hline As-rolled & 20.7 & 3000 & 0.05 & 33.3 & 190 & 83 & 76 \\
\hline Girth Weld & 13.8 & 2000 & 0.05 & 59.5 & 340 & 111 & 101 \\
\hline Girth HAZ & 13.8 & 2000 & 0.05 & 39.9 & 228 & 91 & 83 \\
\hline Normalized & 3.5 & 500 & 0.05 & 49.2 & 281 & 101 & 92 \\
\hline Normalized & 5.2 & 750 & 0.05 & 43.4 & 248 & 95 & 86 \\
\hline Normalized & 6.9 & 1000 & 0.05 & 42.7 & 244 & 95 & 86 \\
\hline Normalized & 13.8 & 2000 & 0.05 & 36.1 & 206 & 87 & 79 \\
\hline
\end{tabular}

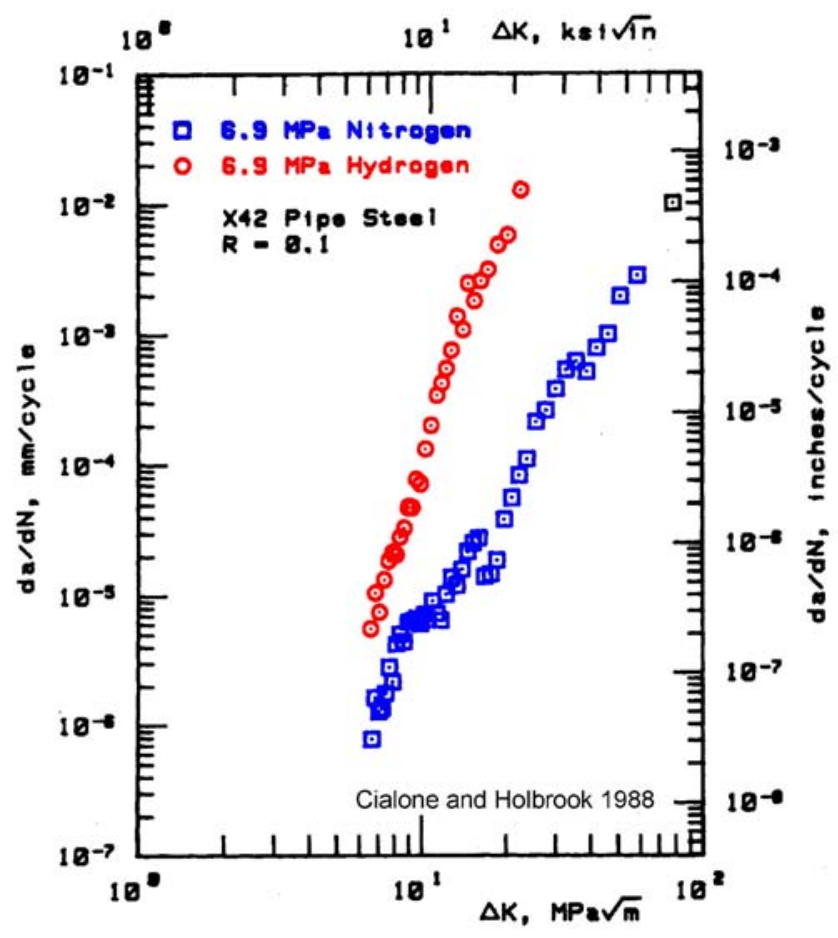

(a) X42

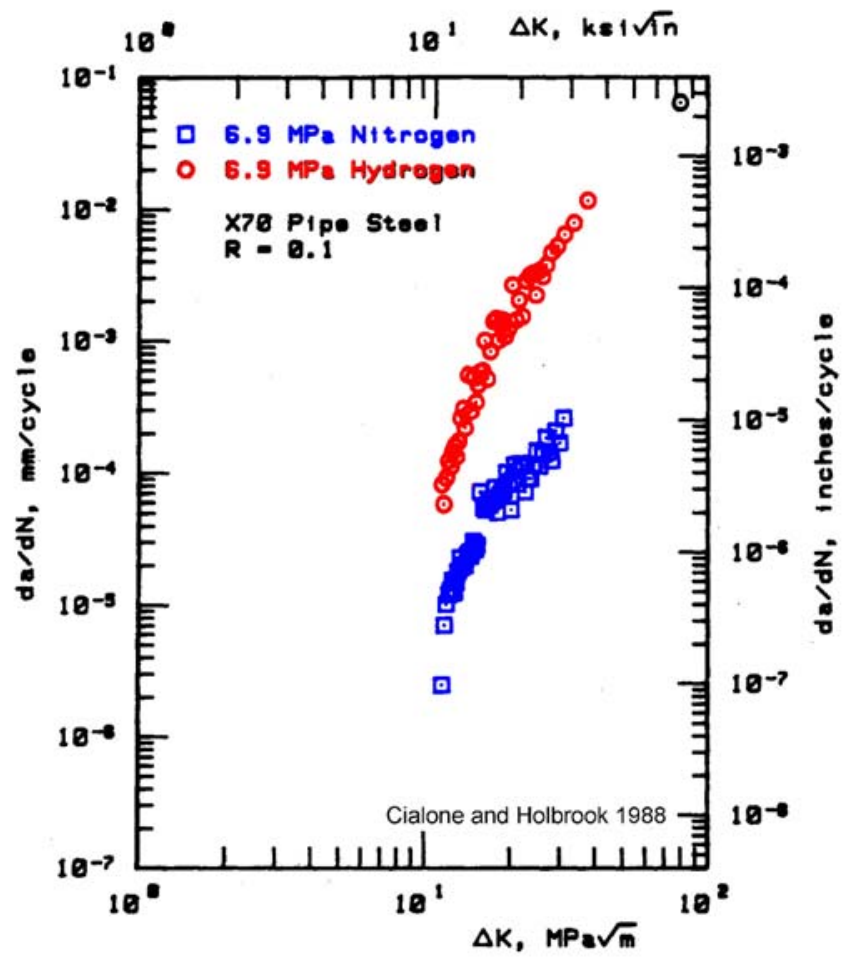

(b) $X 70$

Figure 18 Fatigue crack growth rates (da/dN) for (a) X42 and (b) X70 in 6.9 MPa (1000 psi) hydrogen and in $6.9 \mathrm{MPa}(1000$ psi) nitrogen at stress ratio $\mathrm{R}=0.1[12]$ 


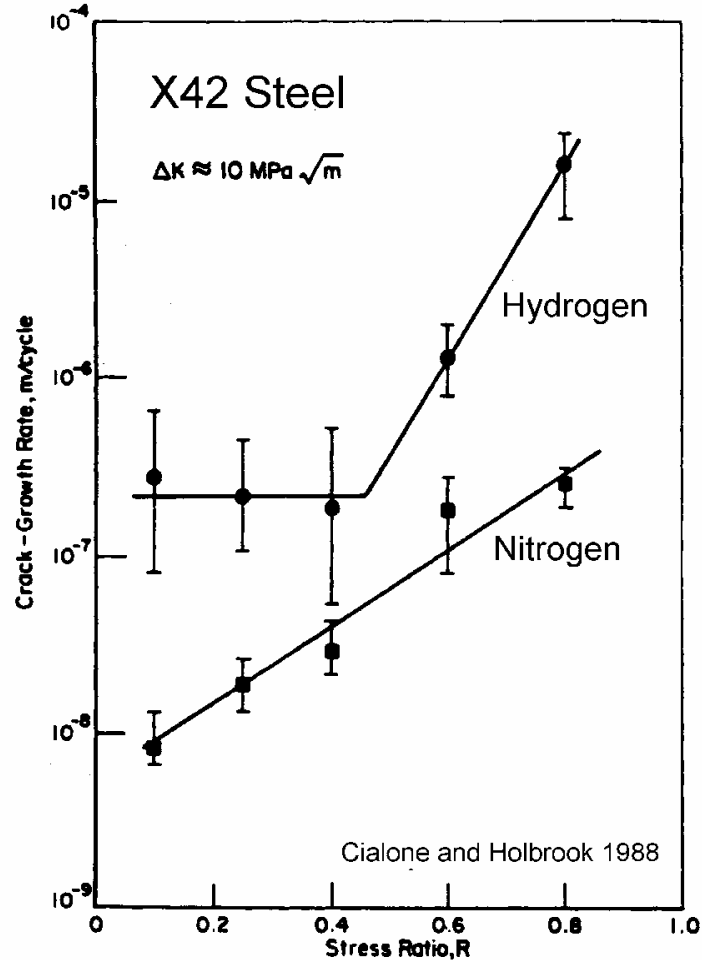

Figure 19 Fatigue crack growth rates (da/dN) for X42 in hydrogen and in nitrogen at various stress ratios $(R)$ [12].

The fracture toughness of the as-rolled and normalized API 5L Grade B line pipe steel obtained by Zawierucha and Xu (2005) [17] was reported in the previous section. The corresponding fatigue crack growth rates with stress ratio $\mathrm{R}=0.1$ under 1.4 and $20.7 \mathrm{MPa}$ hydrogen pressures are shown in Figure 20. It can be concluded that the presence of hydrogen significantly increased the fatigue crack growth rate of the material (20 to 50 times higher than in the air). In addition, over the tested $\Delta \mathrm{K}$ range (i.e., $16.5<\Delta \mathrm{K}<25.3 \mathrm{MPa} \sqrt{\mathrm{m}}$ ), the fatigue crack growth rate seemed insensitive to the pressure of hydrogen (i.e., da/dN only increased about 1.5 times when the hydrogen pressure changed from 1.4 MPa to 20.7 MPa). Additional hydrogen pressures were applied in the fatigue crack growth tests. Figure 21 shows the dependence of fatigue crack growth rate on the hydrogen pressure when $\Delta \mathrm{K}=22 \mathrm{MPa} \sqrt{\mathrm{m}}$. The heat treatment used to normalize the as-rolled material did not affect the fracture toughness and the fatigue crack growth rate of the material. Note that the tensile property change due to the heat treatment can be seen in the inset of Figure 17.

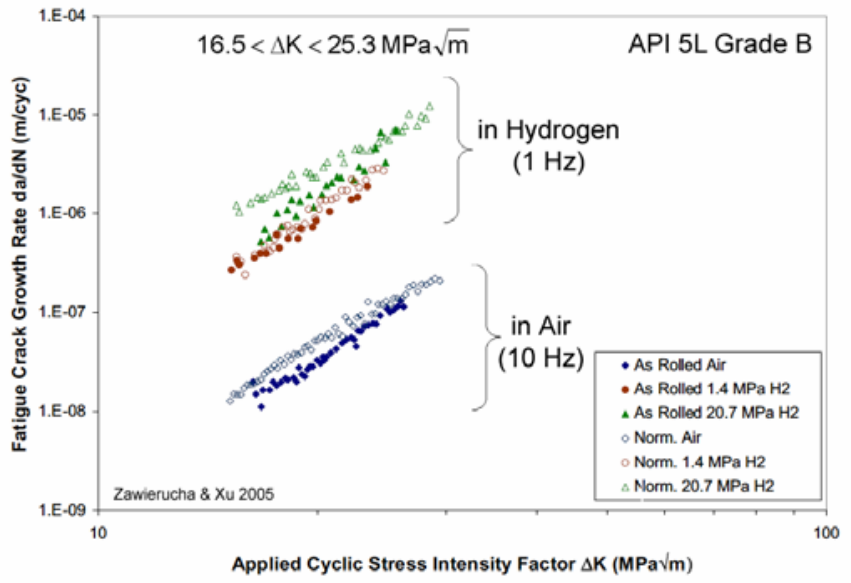

Figure 20 Fatigue crack growth rates (da/dN) for asrolled and normalized API 5L Grade B steels in various pressures of hydrogen $(1 \mathrm{~Hz})$ and in air $(10 \mathrm{~Hz})$ [17].

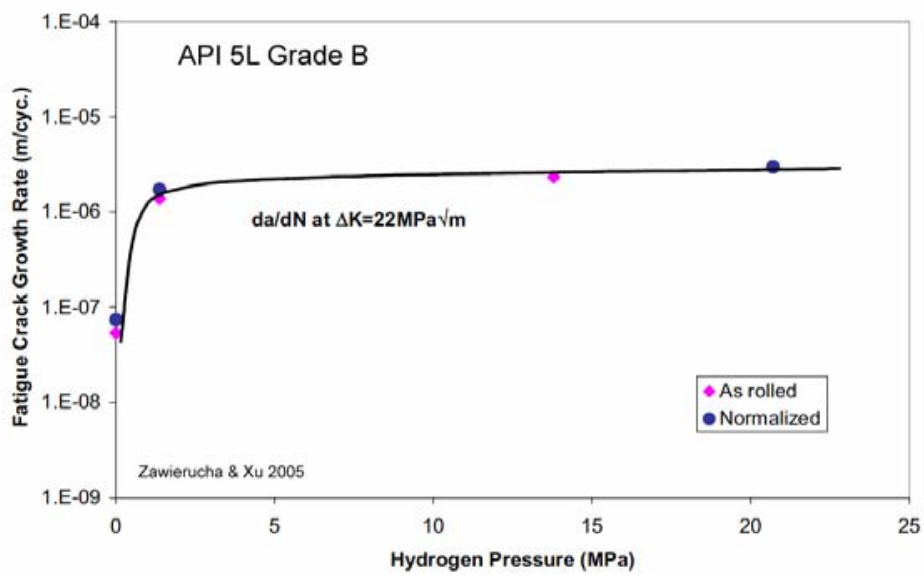

Figure 21 Fatigue crack growth rates (da/dN) for asrolled and normalized API 5L Grade B steels as a function of hydrogen pressure [17]

An extensive investigation of fatigue properties was conducted by Walter and Chandler (1976) [20] for ASME SA105 Grade II steel $(0.23 \% \mathrm{C}$ and $0.62 \% \mathrm{Mn})$ used in highpressure hydrogen compressor systems. Tapered, doublecantilever beam (TDCB) specimens were instrumented and tested in high purity hydrogen up to $103.4 \mathrm{MPa}(15,000 \mathrm{psi})$ at ambient temperature $\left(70{ }^{\circ} \mathrm{F}\right)$. The dependence of fatigue crack growth rate $(\mathrm{da} / \mathrm{dN})$ on the hydrogen pressure $(6.9,68.9$, and 103.4 $\mathrm{MPa}$ or $1000,10,000$, and $15,000 \mathrm{psi}$ ) is shown in Figure 22. The test data of companion specimens in helium are also included for comparison. It can be seen that the crack growth rate is strongly affected by the presence of hydrogen. However, da/dN is approximately the same in different hydrogen pressures when $\Delta \mathrm{K}$ is greater than $33 \mathrm{MPa} \sqrt{\mathrm{m}}$ 
( $30 \mathrm{ksi} \sqrt{\mathrm{in}})$. This behavior is consistent with the results in Figure 21 (Zawierucha and $\mathrm{Xu}$ [17]).

Figure 23 shows the response of $\mathrm{da} / \mathrm{dN}$ as a function of $\Delta \mathrm{K}$ under various loading frequencies for ASME SA-105 Grade II steel in hydrogen. The test data in helium are included for comparison.

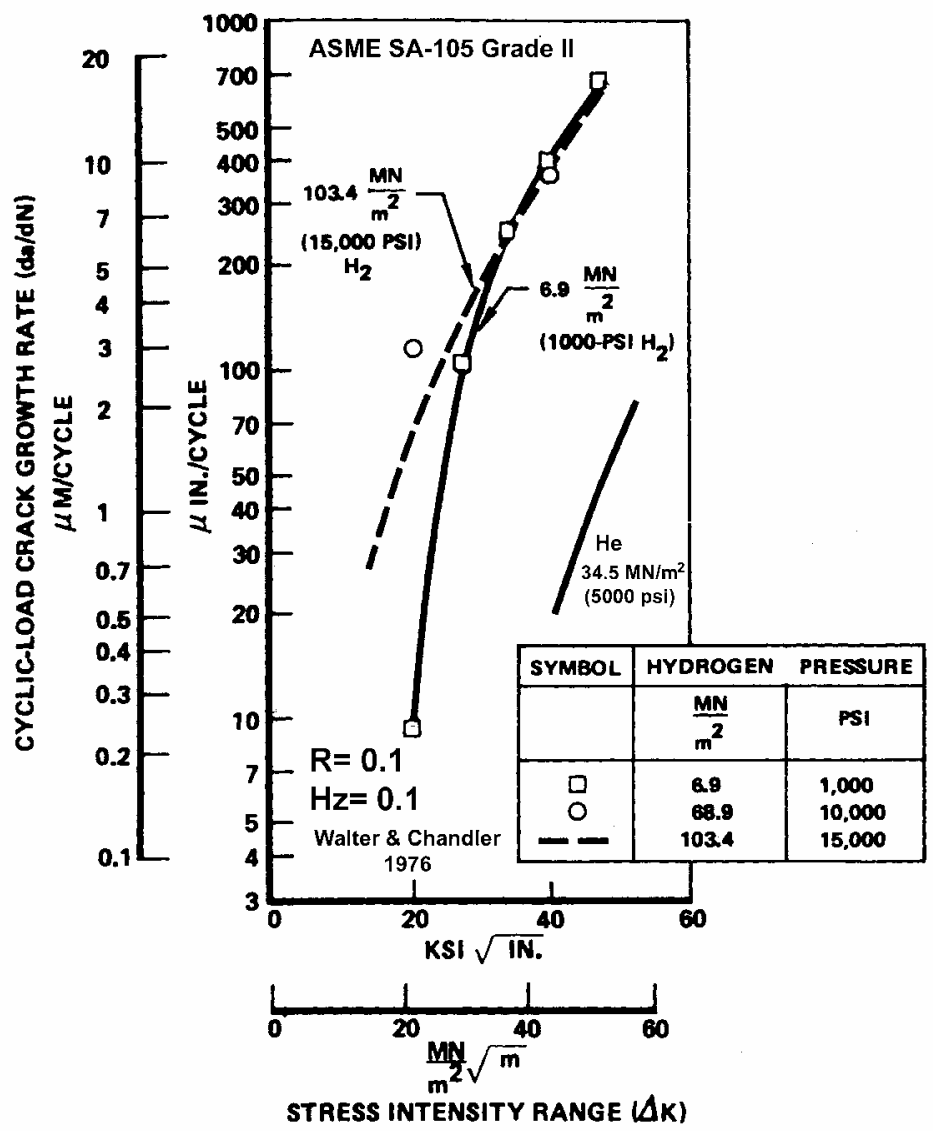

Figure 22 Fatigue crack growth rate for ASME SA-105 Grade II steel exposed to hydrogen up to 15,000 psi under $\mathrm{R}=0.1$ and $0.1 \mathrm{~Hz}$ cyclic load [20]

The effects of stress ratio were also investigated by these authors [20]. They varied the stress ratios (R) with a fixed $\mathrm{K}_{\max }$ in one group of tests, and used a constant $\mathrm{R}=0.1$ but varied $\mathrm{K}_{\max }$ in another group. The $\mathrm{K}_{\max }$ used in this study was below $50 \mathrm{MPa} \sqrt{\mathrm{m}}$, which is about one-half of the typical $\mathrm{K}_{\mathrm{IC}}$ for ASME SA-105 Grade II steel (generally greater than $100 \mathrm{MPa} \sqrt{\mathrm{m}}$ or $91 \mathrm{ksi} \sqrt{\mathrm{in}})$. The test data of Walter and Chandler [20] were shown to fall on a curve which can be defined by a simple Paris power law [21,22] as a function of $\Delta \mathrm{K}$ only (unless $\mathrm{K}_{\max }$ approaches the stress intensity factor for unstable crack growth). This implies that $\mathrm{da} / \mathrm{dN}$ strongly depends on the stress range (or $\Delta \mathrm{K}$ ), and a high $\mathrm{K}_{\max }$ does not significantly affect the fatigue crack growth for this material. Note that Cialone and Holbrook [12] showed the dependence of da/dN on R (Figure 19) for X42 steel.

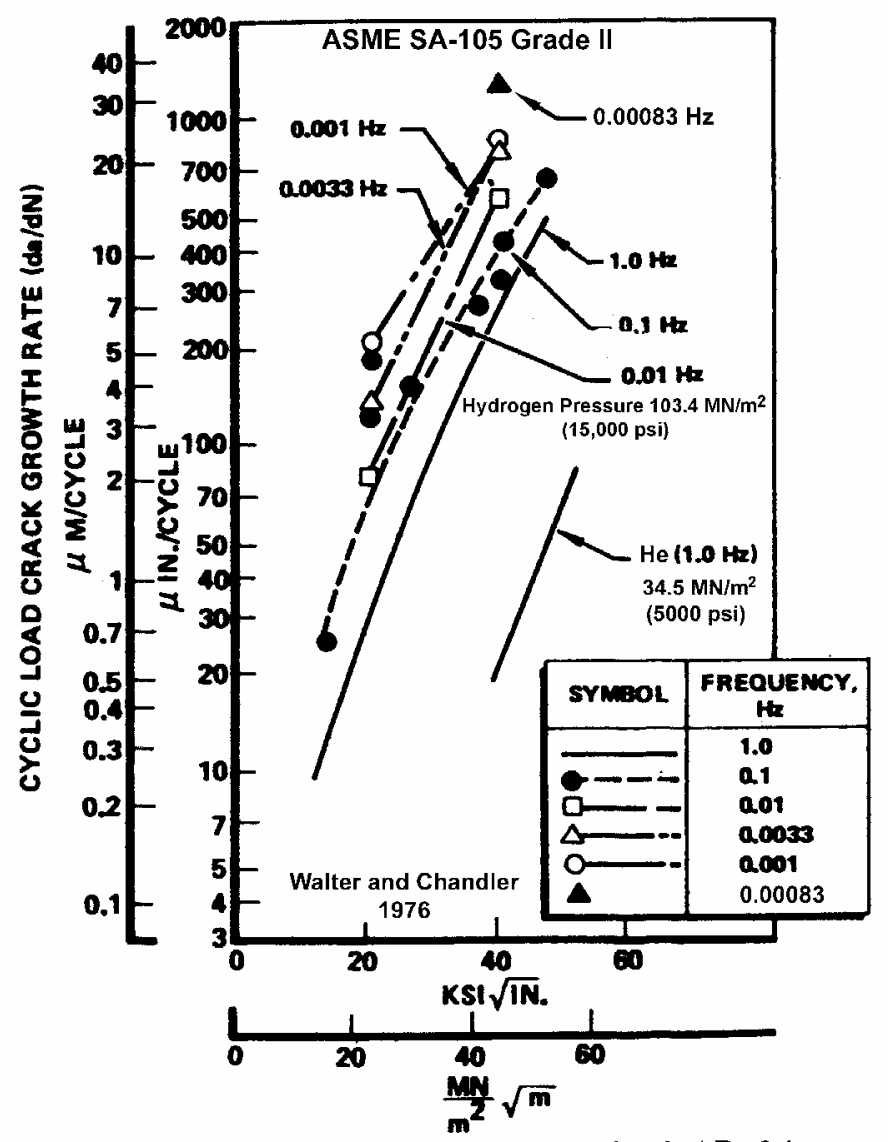

STRESS INTENSITY RANGE $(\Delta K)$ at $R=0.1$

Figure 23 Cyclic frequency effects on ASME SA-105 Grade II steel in 15,000 psi hydrogen $(R=0.1)$ [20]

In general, a tensile overload in fatigue testing causes a retardation in crack propagation because a plastic wake occurs behind the crack tip [23]. Walter and Chandler (1976) [20] reported that a preloading (overload) in air to a stress intensity factor 1.5 times the cyclic $\mathrm{K}_{\max }$ did not seem to affect da/dN in 103.4 MPa (15,000 psi) hydrogen for ASME SA-105 Grade II steel, while the same preloading indeed retarded the subsequent fatigue crack growth when the test was carried out in $34.5 \mathrm{MPa}$ (5000 psi) helium. It appears that the hydrogen embrittlement diminished the plasticity effect in this steel.

\section{CONCLUSIONS}

Tensile properties (yield stress, ultimate tensile stress, elongation, and reduction of area), threshold stress intensity factor (or the critical stress intensity factor at crack arrest), fracture toughness (J-R curve, $\mathrm{J}_{\mathrm{IC}}$, or $\mathrm{K}_{\mathrm{IC}}$ ), and the fatigue crack 
growth rate $(\mathrm{da} / \mathrm{dN})$ which were reported in the open literature for low carbon steel and line pipe steels with up to moderate strengths in the gaseous hydrogen environment have been summarized in this paper. In general, the hydrogen pressure does not have pronounced effects on the yield stress and the UTS. In addition, the hydrogen pressure would either increase or decrease the yield stress and the strain hardening behavior. However, hydrogen has a significant effect on decreasing the ductility of the material (i.e., the elongation and the reduction of area). It was also demonstrated by all the investigators that the hydrogen pressure will significantly reduce the fracture toughness (both initiation and $\mathrm{dJ} / \mathrm{da}$ or tearing capacity) and accelerate the fatigue growth rate.

The hydrogen effects on these mechanical properties of the carbon steel and the pipeline materials depend on many factors such as the pressure and purity of the hydrogen gas, the loading range and loading rate. As a result, the concept of a composite plot to show all the available literature data for comparison purpose would not be possible. However, the collection of literature data is by no means complete, but the diversity of data and dependency of results in test method is sufficient to warrant a design and implementation of a thorough test program. The program would be needed to enable a defensible demonstration of structural integrity of a pressurized hydrogen system. It is essential that the environmental variables be well-defined (e.g., the applicable hydrogen gas pressure range and the test strain rate) and the specimen preparation be realistically consistent (such as the techniques to charge hydrogen and to maintain the hydrogen concentration in the specimens). To facilitate the predictive methodology and the fitness-for-service assessment analyses, the companion tensile testing for the full stress-strain curve should be performed along with the fracture and fatigue tests, which are expected to be an integral part of code and standard development for hydrogen services.

\section{ACKNOWLEDGMENTS}

The authors gratefully acknowledge support from the Concurrent Technologies Corporation and the U.S. Department of Energy, Office of Energy Efficiency and Renewable Energy.

\section{REFERENCES}

1 Specification for Line Pipe, API Specification 5L, 43rd Edition, March 2004, American Petroleum Institute, Washington, DC.

2 Kimura, H., Matsui, H., Kimura, A., Kimura, T., and Oguri, K., 1981, "Softening and Hardening in High Purity Iron and Its Alloys Charged with Hydrogen," Hydrogen Effects in Metals, ed. I. M. Bernstein and A. W. Thompson, The Metallurgical Society of American Institute of Mining,
Metallurgical, and Petroleum Engineers (AIME), Inc., New York, NY, pp. 191-208.

3 Jewett, R. P., Walter, R. J., Chandler, W. T., and Frohmberg, R. P., 1973, Hydrogen Environment Embrittlement of Metals, prepared by Rocketdyne, Division of North American Rockwell, Canoga Park, CA. for National Aeronautics and Space Administration, Washington, DC, NASA Contractor Report NASA CR2163.

4 Hofmann, W. and Rauls, W., 1961, Archiv für das Eisenhüttenwesen, p. 1.

5 Hofmann, W. and Rauls, W., 1962, Dechema Monograph, 45, p. 33.

6 Hofmann, W. and Rauls, W., 1965, "Ductility of steel under the influence of external high pressure hydrogen (Hydrogen embrittlement of plain steel and Armco iron)," Welding J., Research Supplement, 44, pp. 225-S - 230-S.

7 Walter, R. J. and Chandler, W. T., Effects of High-pressure Hydrogen on Metals at Ambient Temperature, Final Report, Contract NAS8-19, NASA, MSFC, Huntsville, Alabama, Rocketdyne, a division of North American Rockwell Corp., Canoga Park, CA., Report R-7780-1,2, 3. Available through U. S. Department of Commerce, National Technical Information Service, N70-18637.

8 Ellis, M. B. D., Bartlett, R. A., and Knott, J. F., "Effects of Prestrain and Dissolved Hydrogen on the Tensile Properties and the Fracture Behavior of Line-Pipe Steels," 1990, Hydrogen Effects on Material Behavior, ed. N. R. Moody and A. W. Thompson, The Minerals, Metals, and Materials Society, Warrendale, PA, pp. 991-1002.

9 Pussegoda, L. N. and Tyson, W. R., 1981, "Relationship between Microstructure and Hydrogen Susceptibility of Some Low Carbon Steels," Hydrogen Effects in Metals, ed. I. M. Bernstein and A. W. Thompson, The Metallurgical Society of American Institute of Mining, Metallurgical, and Petroleum Engineers (AIME), Inc., New York, NY, pp. 349-360.

10 Christenson, D. J., Berstein, I. M., Thompson, A. W., Danielson, E. J., Elices, M., and Gutierrez-Solana, F., 1981, "Hydrogen Compatibility of a Line Pipe Steel," Hydrogen Effects in Metals, ed. I. M. Bernstein and A. W. Thompson, The Metallurgical Society of American Institute of Mining, Metallurgical, and Petroleum Engineers (AIME), Inc., New York, NY, pp. 997-1004.

11 Gutierrez-Solana, F. and Elices, M., 1982, "High-Pressure Hydrogen Behavior of a Pipeline Steel," Current Solutions to Hydrogen Problems in Steels, ed. C. G. Interrante and G. M. Pressouyre, American Society for Metals, Metals Park, OH, pp. 181-185.

12 Cialone, H. J. and Holbrook, J. H., 1988, "Sensitivity of Steels to Degradation in Gaseous Hydrogen," Hydrogen Embrittlement: Prevention and Control, ASTM STP 962, 
ed. L. Raymond, American Society for Testing and Materials, Philadelphia, pp. 134-152.

13 Holbrook, J. H., Cialone, H. J., Mayfield, M. E., and Scott, P. M., 1982, The Effect of Hydrogen on Low-Cycle-Fatigue and Subcritical Crack Growth in Pipeline Steels, Battelle Columbus Laboratories, Columbus, Ohio, available through U. S. Department of Commerce, National Technical Information Service, DE85006685.

14 Loginow, A. W. and Phelps, E. H., 1975, "Steels for Seamless Hydrogen Pressure Vessels,” Corrosion, 31(11), pp. 404-412.

15 Robinson, S. L. and Stoltz, R. E., 1981, “Toughness Losses and Fracture Behavior of Low Strength CarbonManganese Steel in Hydrogen”, Hydrogen Effects in Metals, ed. I. M. Bernstein and A. W. Thompson, The Metallurgical Society of American Institute of Mining, Metallurgical, and Petroleum Engineers (AIME), Inc., New York, NY, pp. 987-993

16 Paris, P. C., Tada, H., Zahoor, A., and Ernst, H., 1979, "The Theory of Instability of the Tearing Mode of Elasticplastic Crack Growth,” Elastic-Plastic Fracture, ASTM STP 668, J. D. Landes, J. A. Begley, and G. A. Clarke, eds., American Society for Testing and Materials, pp. 5-36.

17 Zawierucha, R. and Xu, K., 2005, "Hydrogen Pipeline Steels," Materials Science \& Technology - Materials for the Hydrogen Economy, organized by J. J. Petrovic, I. E. Anderson, T. M. Adams, G. Sandrock, C.F. Legzdins, J.W. Stevenson, and Z.G. Yang, 2005; Materials Science \& Technology 2005, pp. 79-90.

18 ASTM E 1820, Standard Test Method for Measurement of Fracture Toughness, American Society for Testing and Materials.

19 Barsom, J. M. and Rolfe, S., 1999, Fracture and Fatigue Control in Structures: Applications of Fracture Mechanics, 3rd Edition, American Society for Testing and Materials, p. 119.

20 Walter, R. J. and Chandler, W. T., 1976, "Cyclic-load Crack Growth in ASME SA-105 Grade II Steel in Highpressure Hydrogen at Ambient Temperature, "Effect of Hydrogen on Behavior of Materials, ed. A. W. Thompson and I. M. Bernstein, The Metallurgical Society of American Institute of Mining, Metallurgical, and Petroleum Engineers (AIME), Inc., New York, NY, pp. 273-286.

21 Paris, P. C., Gomez, M. P., Anderson, W. P., 1961, “A Rational Analytic Theory of Fatigue," The Trend in Engineering, Vol. 13, pp. 9-14.

22 Paris, P. C. and Erdogan, F., 1960, “A Critical Analysis of Crack Propagation Laws,” Journal of Basic Engineering, Vol. 85, pp. 528-534.

23 Elber, W., 1971, “The Significance of Fatigue Crack Closure,” Damage Tolerance in Aircraft Structures, ASTM
STP 486, American Society for Testing and Materials, Philadelphia, pp. 230-242. 